\title{
Drivers of SME performance: a holistic and multivariate approach
}

\author{
Olubunmi Ipinnaiye • Declan Dineen • \\ Helena Lenihan
}

Accepted: 5 December 2016/Published online: 24 December 2016

(C) The Author(s) 2016. This article is published with open access at Springerlink.com

\begin{abstract}
To examine the drivers of small- and medium-sized enterprise (SME) growth, we adopt a holistic multivariate modelling approach, integrating macroeconomic determinants with the internal (firm characteristics and firm strategy) drivers more commonly investigated in firm growth studies. Utilising such an extended set of variables addresses a gap in the extant firm growth literature in relation to external growth factors, offering novel insights on the seeming randomness of firm growth. Our system generalised method of moments estimation results indicate that the macroeconomic environment influences firm growth both directly and indirectly. Based on the study of manufacturing SME growth in Ireland, our findings provide evidence on the integrated effects of macroeconomic conditions, firm characteristics and firm strategy for SME growth. They also highlight, from a theoretical perspective, the need to acknowledge the multidimensional nature of SME growth.
\end{abstract}

Keywords Firm growth · Firm size · Business cycle · SMEs $\cdot$ Panel data

JEL classifications C23 $\cdot$ D22 $\cdot$ E32 $\cdot$ L25

O. Ipinnaiye $\cdot$ D. Dineen $\cdot H$. Lenihan $(\bowtie)$

Department of Economics, Kemmy Business School, University of Limerick, Limerick, Ireland

e-mail: helena.lenihan@ul.ie

\section{Introduction}

Small and medium-sized enterprises (SMEs) ${ }^{1}$ are at the forefront of the industrial policy agenda owing to their role in creating jobs, stimulating innovation and promoting entrepreneurial skills (Audretsch 2004; Rigtering et al. 2014). The extensive literature on firm growth beginning with Gibrat's Law in 1931 (see Coad 2009; Peric and Vitezic 2016) offers an understanding of firm heterogeneity arising from several sources including firm-specific characteristics (e.g. firm size, age and ownership) and firm strategy variables (e.g. training and innovative activity). These sources are significant factors in explaining SME growth. However, little is known about the role of macroeconomic conditions, as well as the combined effects of internal and external growth drivers in the SME growth process. More scope for research exists in this area. Indeed, Stam (2010) notes the need for an enhanced and extended set of explanatory variables in empirical studies to provide more insights on the seeming randomness of firm growth. Our study seeks to contribute to this debate. We argue that SME performance is determined by the firm's inherent characteristics and firm strategy, as well as the external (macroeconomic) environment in which it operates. We, therefore, develop and test a holistic multivariate modelling approach which integrates three sets of determinants in explaining SME performance: (1) firm characteristics, (2) firm strategy and (3)

\footnotetext{
${ }^{1}$ SMEs are defined as firms with less than 250 employees (European Commission 2003).
} 
macroeconomic conditions. The first two groups of factors are internal to the firm, while the latter group lies outside of the firm's control and is frequently omitted in firm growth analyses.

Our paper extends and contributes to the firm growth literature in three ways. First, we provide much needed empirical evidence on the interactions between macroeconomic conditions and SME growth. In contrast to other studies (e.g. Mazzucato and Parris 2015), which examine internal factors such as firm size, age and innovation activity and do not consider macroeconomic variables, we focus on the macroeconomic environment, together with the internal determinants of firm growth. Given that fluctuations in macroeconomic conditions effect changes in firms' prices and output levels, thereby influencing firms' decisions, strategy and subsequent performance, we consider this approach to be more appropriate. Our treatment of macroeconomic factors as important determinants of firm growth, rather than merely as control variables, differentiates this research from previous studies (e.g. Beck et al. 2005; Mateev and Anastasov 2011). Second, we investigate the integrated effect of internal (firm characteristics and firm strategy) and external factors (macroeconomic conditions) on SME growth within a holistic model. Thus, we provide empirical evidence on the factors influencing SME performance and the exact channels through which this occurs. Our results show that firm growth is explained by a combination of firm characteristics, firm strategy and macroeconomic conditions. Third, we use three discrete firm growth measures to capture the possible divergent effects of growth drivers on different aspects of the firm's performance. We investigate contingent conditions for SME growth (employment, turnover and productivity) using the system generalised method of moments (SYS-GMM) estimation method to analyse a large unbalanced panel dataset of manufacturing SMEs in Ireland for the period 1991-2007. Turnover and employment growth measure the firm's actual performance and potential productive capacity, respectively (Bottazzi et al. 2008), while productivity growth assesses its efficiency of resource use in producing a given level of output. This approach also incorporates the specific objectives of the key stakeholders (e.g. the firm, policy makers, employees and consumers). We find evidence to support the use of different firm performance measures which take account of the multidimensional nature of SME growth. To support the robustness of our results (as detailed later in Sect. 4.4), we repeat the analyses for sub-samples of firms categorised by technology intensity and whether the firm entered, left or remained in the sample for the study period.

The importance of SMEs is grossly underestimated. SMEs accounted for 99.8 and $99.7 \%$ of active firms in Ireland in 2007 and 2012, respectively, and $99.8 \%$ of firms in the EU-27 in 2008 and 2012 (CSO 2014; European Commission 2011, 2012). In relation to job creation, SMEs provided 71 and $68 \%$ of jobs in Ireland in 2007 and 2012, respectively. This is broadly in line with employment trends in the EU-27-66.7\% in 2008 and $67.4 \%$ in 2012 (European Commission 2011, 2012). Despite an increased policy focus on SMEs in Ireland since the mid-1990s (Andreosso-O'Callaghan and Lenihan 2011; Bailey and Lenihan 2015), research in this area remains largely neglected. The manufacturing sector is essential to innovation and technological progress and is, thus, a key driver of economic growth. Importantly, manufacturing growth also supports nonmanufacturing jobs up and down the supply chain. Furthermore, SMEs are likely to be more vulnerable to changes in the macroeconomic environment owing to being financially constrained (Christopherson 2015; Lai et al. 2016). All of the above justify our focus on manufacturing SMEs.

Ireland serves as an interesting laboratory in which the integrated effects of firm characteristics, strategy and macroeconomic conditions on SME performance can be investigated. We examine manufacturing SME performance during Ireland's so-called Celtic Tiger period (1991-2007) when the country experienced a macroeconomic transformation. Gross national product (GNP) grew at a rate in the range of 5-15\% every year from 1991 to 2006 (Dineen et al. 2012). However, two distinct growth phases can be identified-an export-led growth phase (1991-2000) and a credit-led domestic demand-driven growth phase (2001-2007). After 2000 , export-led manufacturing growth, the dominant engine of Ireland's economic transformation during the 1990s, gave way to an unsustainable credit-led property price bubble, financed by net external borrowing (Honohan 2010). To the best of our knowledge, this is the first attempt at investigating the performance of SMEs in Ireland taking account of the discrete growth phases during this period. The significant shifts in the drivers of growth and in the sectoral performance of the economy after 2000 provide a natural experiment on the 
effect of macroeconomic conditions on SME performance. Our results not only contribute to the sparse literature on the link between macroeconomic conditions and firm growth but also provide insights on the combined effects of firm-characteristic, firm strategy and macroeconomic factors on SME performance in Ireland within a holistic framework. Although Ireland is used as the locale for this study, this research provides transferrable lessons (from knowledge, empirical, theoretical and policy perspectives), which remain relevant for researchers in other country contexts. We address these lessons in Sect. 5.

The rest of the paper is organised as follows: Sect. 2 presents the theoretical background, and Sect. 3 describes the dataset and model specifications. Our empirical findings are discussed in Sect. 4, while Sect. 5 concludes.

\section{Theoretical background}

Heterogeneity in the performance of firms, even within the same narrowly defined industries, is well noted in the literature (Caves 1998). Based on the evolutionary and resource-based views of the firm, these performance differences have been attributed to variations in the resources and capabilities embedded in the firm, the strategic choices made in exploiting these resources and capabilities, as well as responses to changes in the business environment (Nelson and Winter 1982; Lockett et al. 2009). Our use of a holistic modelling approach to study firm performance is, therefore, motivated by the need to explain this observed heterogeneity and derives from the wide range of drivers examined in empirical firm performance studies. We present a holistic model which relates manufacturing firm growth to both its internal (firm characteristics and firm strategy) and external (macroeconomic environment) determinants. This approach is necessary because macroeconomic conditions not only have a direct effect on firm performance, but we also need to consider possible linkages between the macroeconomic environment and the internal determinants of firm growth. Hence, macroeconomic conditions may have an indirect effect on firm performance through the strategies adopted by the firm, and the specific impact of macroeconomic variables on firm growth may also be conditional on firm characteristics.

\subsection{Internal determinants of firm growth}

In selecting the firm-characteristic variables examined in our analysis, we draw on existing research which has focused on the interaction between firm performance and variables such as firm size, initial level of productivity, industry minimum efficient size (MES), industry growth, and following the Schumpeterian tradition, industry concentration (Delmar and Wennberg 2010; Huynh et al. 2010; Mazzucato and Parris 2015). The first two variables measure the firm's starting quality, while the latter three account for industry characteristics. Foreign firms have been found to be more successful relative to indigenous firms in terms of employment and turnover performance (Halkos and Tzermes 2010). Thus, we include a binary variable, nationality of ownership, to assess the effect of foreign ownership on SME growth. Based on previous empirical findings as detailed above, we expect to find a positive growth effect for all firm-characteristic variables, while we expect the initial firm size to have a negative impact on firm growth.

Drawing on the extant literature, the strategy variables included in our analysis are trade, training, research and development (R\&D) and receipt of public support such as grants/subsidies (Bernini and Pellegrini 2011; Haller 2012; Jones et al. 2013; Nunes et al. 2013a). With increasing globalisation, trade has become an important tool for improving SME growth. SMEs learn from exporting, which increases their competitiveness, productivity and overall performance (Love and Ganotakis 2013). Exports also provide access to global markets - this is particularly important for SME performance in small open economies such as Ireland. Importing may offer SMEs access to higher quality and a wider range of inputs at lower cost (Vogel and Wagner 2010). This may lead to better product quality and higher productivity. Thus, we include a categorical variable, trade, with no trade activity as the omitted category. This controls for performance heterogeneity due to a firm engaging only in import or export activities. We also include a third category to control for the simultaneous positive effect of both exporting and importing (two-way trade) in line with other studies (Haller 2012).

Training represents the firm's investment in human capital and is a critical part of the firm's productive resources, which confer competitive advantages according to the resource-based view of the 
firm (del Valle and Castillo 2009). Training is, therefore, a useful strategy in upgrading workers' skills and knowledge to ensure the SME remains competitive and productive. Investment in R\&D is posited to stimulate better performance in SMEs by potentially transforming the firm's internal capabilitiesthis engenders greater flexibility and resilience during adverse macroeconomic conditions (Artz et al. 2010). The case for government intervention in the provision of public support to SMEs is predicated on market failure and, more recently, systemic failure arguments (Haapanen et al. 2014). It is argued that public support for SMEs is necessary to overcome growth obstacles such as financing constraints (Nunes et al. 2013b). There is some ambiguity in empirical studies on the link between public support and firm growth. Based on the prevailing literature, we expect to find a positive effect for turnover and employment growth and a negative effect for productivity performance (Duch et al. 2009; Bernini and Pellegrini 2011).

\subsection{External determinants of firm growth-macroeconomic environment}

The literature on the influence of macroeconomic conditions on firm performance is sparse, with many studies employing year dummy variables (e.g. Coad and Rao 2008; Navaretti et al. 2014). Other studies, such as Holly et al. (2013), have examined the effect of gross domestic product (GDP) growth on crosssectional sales growth rates. However, firmcharacteristic and firm strategy variables are not considered in these analyses. A limited number of crosscountry studies (e.g. Beck et al. 2005) have investigated the effect of macroeconomic factors such as GDP growth and inflation on sales growth, but these studies suffer from similar measurement weaknesses. ${ }^{2}$ Furthermore, the endogeneity of the macroeconomic variables is often poorly addressed. We combine our within-country panel of manufacturing SME firmlevel data with macroeconomic variables, such as inflation and unemployment rates, to reflect the

\footnotetext{
${ }^{2}$ Cross-country studies are generally hampered by definitional and measurement issues caused by cross-country differences in coverage, unit of observation, classification of activity and data quality (Bartelsman et al. 2009).
}

impact of changes in prices and the labour market on firm performance. ${ }^{3}$ We also define the macroeconomic environment in terms of the real effective exchange rate (REER) and domestic credit to the private sector as a percentage of GDP. These variables measure the effects of national competitiveness and the availability of credit on SME growth respectively. We expect to find a positive association between credit growth and firm growth and a negative relationship between inflation and firm growth. However, the link between the REER index, the unemployment rate and firm growth is not clear a priori.

In summary, following evidence from both theoretical and empirical literatures, we test the following hypotheses:

H1: The initial firm size is negatively related to SME employment and turnover growth.

H1a: The initial firm size has a positive effect on SME productivity growth.

H2: The firm's initial level of productivity is positively associated with SME growth.

H3: Foreign ownership is positively related to SME growth.

H4: SMEs which engage in trade activities are likely to grow more.

H5: SMEs which invest in training are likely to grow more.

H6: R\&D investment is positively related to SME growth.

H6b: R\&D intensity has a positive effect on SME growth.

H7: The receipt of public support such as subsidies has a positive effect on the growth of SMEs.

H8: The availability of credit has a positive effect on SME growth.

H9: An increase in aggregate price inflation is associated with lower growth in SMEs.

\footnotetext{
${ }^{3}$ Given that $99.7 \%$ of firms in the Irish economy are SMEs (CSO 2014), it is possible that the GDP firm performance relation is likely to be endogenous, as higher GDP growth could lead to improved SME performance and vice versa. Results from Granger causality tests confirm a significant two-way causal relationship between real GDP and each of the firm growth variables. GDP was included in our growth models for robustness checks; results were, however, more robust and consistent with a priori expectations when real GDP was excluded. Thus, GDP is not included in our reported results.
} 
H10: The aggregate unemployment rate is negatively associated with SME growth.

H11: A decline in national competitiveness negatively affects SME growth.

In addition to investigating the individual effects of the determining factors on firm growth, it is also important to consider possible interactions between the three sets of determining factors (i.e. firm characteristics, firm strategy and the macroeconomic environment) and the dependent variable (firm growth). This provides an understanding of the channels through which growth occurs. To some extent, micro-level performance is governed by macroeconomic conditions, which in turn impact aggregate economic performance. For instance, firm productivity growth is a major source of economic growth and competitiveness (OECD 2012) - productivity increases bring about higher profits, higher wages and price savings, which then feed into the macroeconomy through increased consumer spending, higher exports and more investments, thus increasing GDP and overall economic growth. Also, firm strategy may be determined by the macroeconomic environment. An increase in the real effective exchange rate would make exports less competitive and imports cheaper, with attendant implications for the performance of domestic firms (Caglayan and Demir 2014) — this may subsequently impact on the firm's decision to either export or import. Firm strategy such as training may drive subsequent growth due to unobserved factors such as managerial and workforce qualities which may influence both growth and the firm strategy. Investments in training may be driven by the firm's performance, with high growth firms more likely to invest in training (CEDEFOP 2011). Moreover, participation in international markets may enhance firm performance due to learning effects, while high-growth firms may selfselect into exporting and importing (Castellani et al. 2010). A holistic approach to the investigation of firm growth, as argued in this research, is therefore essential in dealing with the possible endogeneity problems highlighted above. By addressing this hitherto neglected area, this study makes a significant theoretical contribution to the extant firm performance literature. We summarise the theoretical underpinnings of this research in Fig. 1, which presents the measures of firm growth to be analysed, as well as the internal and external variables which may influence SME growth, and the corresponding hypotheses discussed above. This figure also illustrates the interactions between the explanatory and dependent variables.

\section{Data description and model specification}

This section describes our dataset, along with the variables and firm performance model.

\subsection{Dataset}

We use data from the Census of Industrial Production (CIP) dataset collected by the Irish Central Statistics Office (CSO), covering the period 1991-2007. The CIP is an annual census of all manufacturing firms in Ireland with three or more persons engaged, and the dataset offers some unique features. First, it provides comprehensive coverage of all manufacturing firms, including small firms ( $<50$ employees) and, more specifically, micro-sized firms ( $<10$ employees). The latter group of firms are frequently overlooked in many firm performance studies (Reid 2006). Additionally, the dataset is maintained with unique firm identifiers that allow firms to be tracked across years. The original CIP dataset, for our sample period 1991-2007, is an unbalanced panel consisting of 78,599 observations on 11,319 firms in the 2-digit National Classification of Economic Activities (NACE) sectors 10-41. ${ }^{4}$ Within the larger dataset, we focus on manufacturing SMEs (NACE 15-37). Data cleaning involved dropping firms with only 1 year of observation, firms with nonconsecutive observations and firms with missing data which could not be imputed-leaving an unbalanced panel of 7915 firms and 67,366 observations. The number of observed firms varies across the years - in 1991, we observe 3484 firms, while in 2007, this increased to 3618. We deflate turnover using two-digit sectoral level output prices obtained from the EU KLEMS database (EU KLEMS 2011). ${ }^{5}$

\footnotetext{
${ }^{4}$ Although the dataset is based on a census, a firm may not be present in all years due to any one of the following reasons: the firm closes down, a foreign firm exits Ireland and reclassification of a firm to another industry (e.g. from manufacturing to services) due to a change in its predominant activity in the reporting period.

${ }^{5}$ All monetary values are stated in thousands of Euro. Monetary values for the pre-Euro period (1991-2000) are converted to Euro at the European Central Bank conversion rate of $€ 1=$ IEP 0.787564.
} 
Fig. 1 A holistic multivariate framework for SME growth

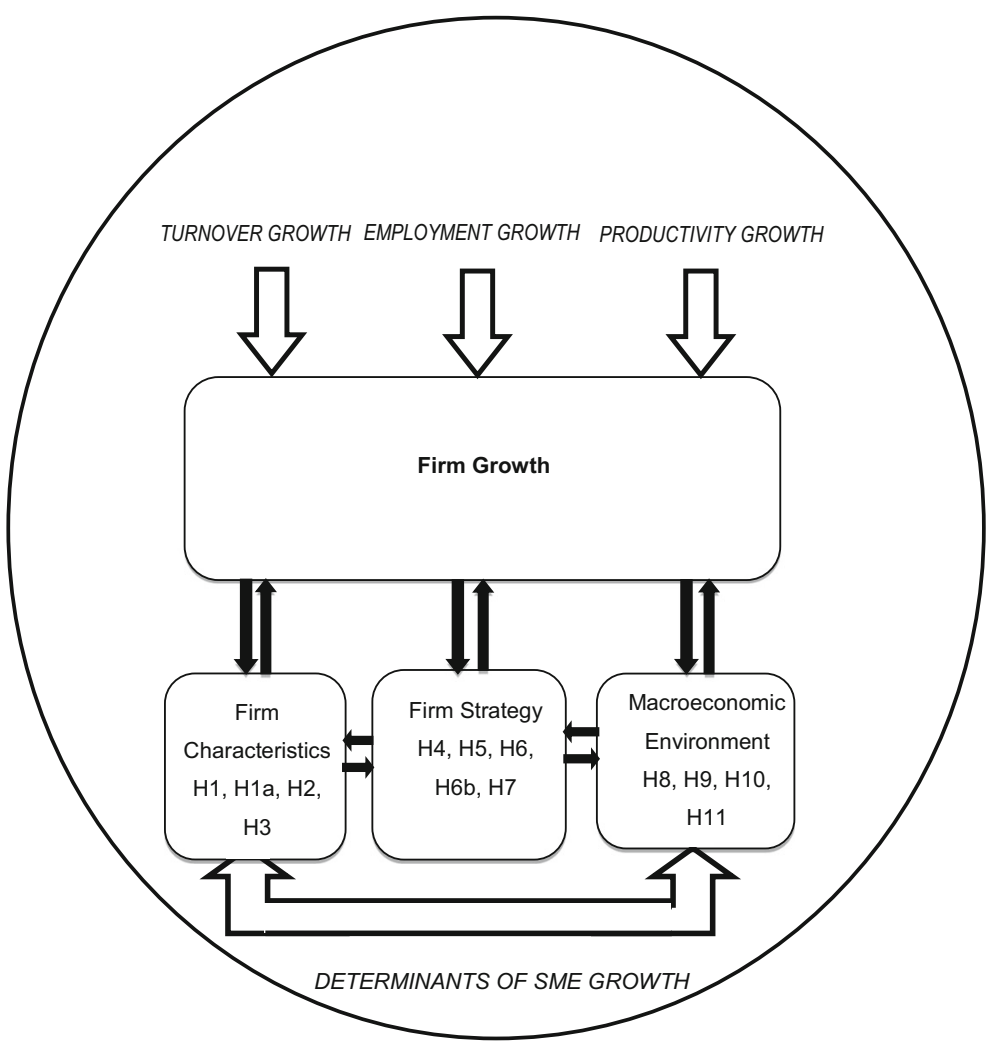

\subsection{Summary statistics}

Following the European Commission (2003) definitions, we classify firms as micro-sized firms ( $<10$ employees), small firms (10-49 employees) and medium-sized firms (50-249 employees). Table 1, which provides a breakdown of the sample by size class, reveals right skewness in the distribution, with proportionately more micro-sized and small firms than medium-sized firms. The former accounted for $83 \%$ of firms in 1991 and $85 \%$ in 2007.

Table 2 presents the means, standard deviations and definitions of our variables. The standard deviations indicate significant variations in growth, with mean growth rates ranging from $2 \%$ (employment growth)

Table 1 Firm distribution by size class

\begin{tabular}{lll}
\hline & 1991 & 2007 \\
\hline Micro (<10 employees) & 1237 & 1396 \\
Small (10-49 employees) & 1677 & 1662 \\
Medium (50-249 employees) & 570 & 560 \\
Total & 3484 & 3618
\end{tabular}

Source: Authors' calculations from CIP dataset, 1991-2007 to $6 \%$ (turnover growth). Mean employment growth is also greatly exceeded by mean turnover and productivity growth. Furthermore, with respect to firmcharacteristic and strategy variables, $11 \%$ of firms in the sample are of foreign ownership, while 51 and $28 \%$ of the firms reported training costs and $R \& D$ expenditure respectively. The pairwise correlation coefficients for each of the research variables, presented in Table 8 (see Appendix), indicate the absence of high correlations between the determining variables.

We further disaggregate the sample by trade activity as detailed in Table 3. The number of non-traders declined from $36 \%$ of the total number of firms in 1991 to $32 \%$ in 2007. Interestingly, all traders in 1991 engaged in export activity only, whereas, in 2007, traders were found in all trade categories - there were more two-way traders $(57 \%)$ relative to other trade categories (import only and export only). Overall, the results suggest the relative importance of two-way trade for SMEs in Ireland.

As indicated earlier in Sect. 1, two distinct macroeconomic growth phases can be identified. We investigate the statistical validity of a structural break in the dataset post-2000. The Chow test results (at the 5\% significance level) confirm a structural break for all 


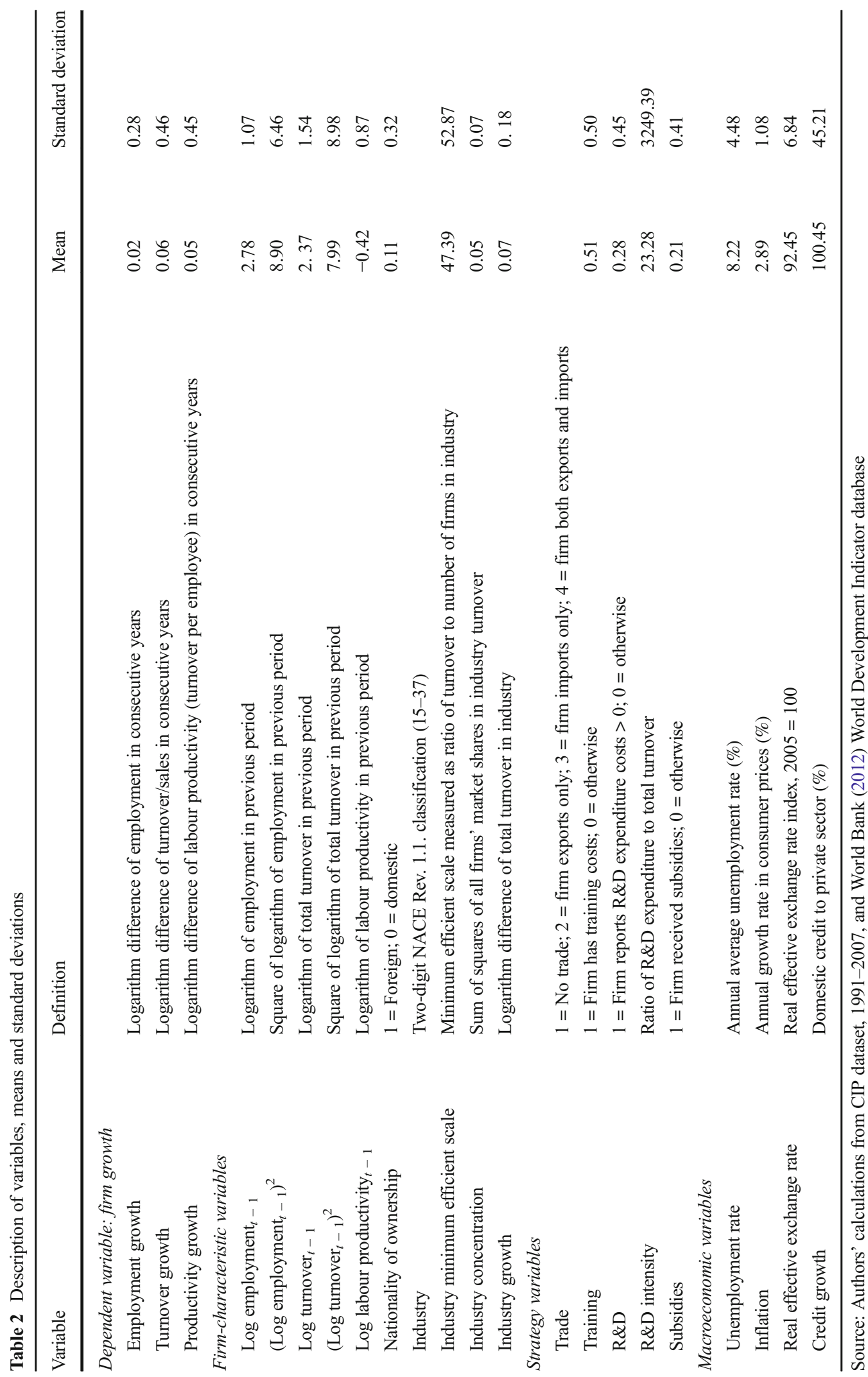


Table 3 Firm distribution by trade activity

\begin{tabular}{lll}
\hline & 1991 & 2007 \\
\hline No trade & 1241 & 1151 \\
Export only & 2243 & 269 \\
Import only & Nil & 792 \\
Export and import & Nil & 1406 \\
Total & 3484 & 3618 \\
\hline
\end{tabular}

Source: Authors' calculations from CIP dataset, 1991-2007

growth variables - turnover $(F$ test $=175.72)$, employment $(F$ test $=6.88)$ and productivity $(F$ test $=81.71)$. Additionally, a visual inspection of the summary statistics, detailed in Table 4, reveals significant differences in

Table 4 Summary statistics across the two growth periods, 19912007

\begin{tabular}{|c|c|c|c|c|}
\hline & \multicolumn{2}{|c|}{$1991-2000$} & \multicolumn{2}{|c|}{ 2001-2007 } \\
\hline & Mean & $\begin{array}{l}\text { Std. } \\
\text { dev. }\end{array}$ & Mean & $\begin{array}{l}\text { Std. } \\
\text { dev. }\end{array}$ \\
\hline \multicolumn{5}{|c|}{ Dependent variable: firm growth } \\
\hline Employment growth & 0.028 & 0.270 & 0.005 & 0.290 \\
\hline Turnover growth & 0.090 & 0.461 & 0.033 & 0.457 \\
\hline Productivity growth & 0.062 & 0.455 & 0.030 & 0.438 \\
\hline \multicolumn{5}{|l|}{ Firm-characteristic variables } \\
\hline Log employment $t_{t-1}$ & 2.837 & 1.055 & 2.717 & 1.087 \\
\hline$\left(\text { Log employment } t_{t-1}\right)^{2}$ & 9.168 & 6.467 & 8.565 & 6.424 \\
\hline Log turnover ${ }_{t-1}$ & 2.185 & 1.538 & 2.585 & 1.530 \\
\hline$\left(\text { Log turnover } \text { t }_{t-1}\right)^{2}$ & 7.141 & 8.341 & 9.024 & 9.593 \\
\hline $\begin{array}{l}\text { Log labour } \\
\text { productivity }_{t-1}\end{array}$ & -0.651 & 0.841 & -0.128 & 0.826 \\
\hline Industry growth & 0.097 & 0.165 & 0.032 & 0.187 \\
\hline $\begin{array}{l}\text { Industry minimum } \\
\text { efficient scale }\end{array}$ & 37.323 & 32.075 & 61.069 & 69.770 \\
\hline Nationality of ownership & 0.125 & 0.331 & 0.099 & 0.299 \\
\hline \multicolumn{5}{|l|}{ Strategy variables } \\
\hline Training & 0.630 & 0.482 & 0.343 & 0.474 \\
\hline $\mathrm{R} \& \mathrm{D}$ & 0.262 & 0.440 & 0.314 & 0.464 \\
\hline $\mathrm{R} \& \mathrm{D}$ intensity & 40.398 & 4281.93 & 0.039 & 4.123 \\
\hline Subsidies & 0.296 & 0.456 & 0.111 & 0.314 \\
\hline \multicolumn{5}{|l|}{ Macroeconomic variables } \\
\hline Unemployment & 11.050 & 3.991 & 4.386 & 0.234 \\
\hline Inflation & 2.605 & 1.098 & 3.297 & 0.918 \\
\hline $\begin{array}{l}\text { Real effective exchange } \\
\text { rate }\end{array}$ & 89.311 & 4.050 & 96.709 & 7.522 \\
\hline Credit & 70.085 & 23.384 & 141.671 & 33.549 \\
\hline
\end{tabular}

Source: Authors' calculations from CIP dataset 1991-2007 the mean values of the variables across the two subperiods (1991-2000 and 2001-2007). Specifically, we find a considerable divergence between both periods for all three firm growth measures. There was also a significant decline in the number of firms reporting training costs, as well as the number of firms in receipt of subsidies. In relation to the macroeconomic variables, credit to the private sector grew more than twofold in 2001-2007, while unemployment declined by more than half in the same period. These results suggest that an investigation of SME growth in Ireland across the two distinct growth phases is apposite.

Table 5 presents the number of firms, mean size and mean employment as well as turnover growth rates by industry sector. Again, this reveals considerable heterogeneity across industries. The highest concentration of firms was found in the 'food products and beverages' industry $(15.1 \%$ of the total number of firms in the sample in 1991). The 'medical, precision and optical instruments, watches and clocks' industry had the highest average growth in employment $(4.6 \%)$ and turnover $(13.8 \%)$, while the lowest employment $(-3.9 \%)$ and turnover $(-0.1 \%)$ growth rates were found in the 'wearing apparel; leather and leather products' industry.

\subsection{Model specification}

Following other studies (e.g. Peric and Vitezic 2016), we estimate the following equation to analyse the drivers of firm growth:

$$
\begin{aligned}
\Delta \ln (S)_{i, t}= & \beta_{0}+\beta_{1} \ln (S)_{i, t-1}+\beta_{2} \ln \left(S_{i, t-1}\right)^{2} \\
& +\beta_{3} X_{i, t-1}+\varepsilon_{i, t}
\end{aligned}
$$

where $\Delta \ln (S)_{i, t}$ is the growth of firm $i$ at time $t$ (measured alternatively in terms of employment, turnover and productivity), ${ }^{6} X_{i, t}$ is a vector of determinants

\footnotetext{
${ }^{6}$ Measuring firm growth over one period (annually) is common practice in much of the firm growth literature. See for example Yang and Huang (2005); Lotti et al. (2009); Daunfeldt and Elert (2013); and Mazzucato and Parris (2015). As detailed by Mazzucato and Parris (2015), the use of an annual growth measure makes it possible to account for the changing dynamics of firm growth over time and to include firms which enter the sample for a short period of time, thereby maximising the number of growth observations for all firms. In addition to our estimations over the entire sample period (1991-2007), we also truncate the business cycle into two sub-periods, 1991-2000 and 2001-2007-corresponding to the two distinct growth phases in the Irish economy. This approach, takes account of possible variations in the macroeconomic environment during the whole study period, and avoids the loss of firm growth observations.
} 
Table 5 Number of firms, mean size and growth rates by industry sector, 1991-2007

\begin{tabular}{|c|c|c|c|c|}
\hline \multirow[t]{2}{*}{ Industry } & \multirow{2}{*}{$\begin{array}{l}\text { Number of } \\
\text { firms }\end{array}$} & \multicolumn{3}{|l|}{ Mean } \\
\hline & & $\begin{array}{l}\text { Number of } \\
\text { employees }\end{array}$ & $\begin{array}{l}\text { Employment } \\
\text { growth }\end{array}$ & $\begin{array}{l}\text { Turnover } \\
\text { growth }\end{array}$ \\
\hline Food products and beverages (15) & 528 & 36.83 & 0.020 & 0.053 \\
\hline Textiles (17) & 153 & 26.20 & -0.005 & 0.019 \\
\hline Wearing apparel; leather and leather products $(18,19)$ & 211 & 31.24 & -0.039 & -0.001 \\
\hline Wood and wood products (20) & 184 & 21.13 & 0.024 & 0.006 \\
\hline Pulp, paper and paper products (21) & 87 & 40.19 & -0.001 & 0.060 \\
\hline Publishing and printing, reproduction of recorded media (22) & 327 & 22.59 & 0.017 & 0.072 \\
\hline Chemicals and chemical products (24) & 163 & 48.97 & 0.035 & 0.091 \\
\hline Rubber and plastic products (25) & 202 & 32.36 & 0.019 & 0.075 \\
\hline Other non-metallic mineral products (26) & 162 & 25.68 & 0.033 & 0.068 \\
\hline Basic metals (27) & 35 & 23.29 & 0.031 & 0.031 \\
\hline Fabricated metal products except machinery and equipment (28) & 445 & 21.46 & 0.022 & 0.068 \\
\hline Machinery and equipment n.e.c. (29) & 264 & 26.58 & 0.013 & 0.060 \\
\hline $\begin{array}{l}\text { Office machinery and computers; radio, television and communication } \\
\text { equipment and apparatus }(30,32)\end{array}$ & 84 & 51.89 & 0.036 & 0.106 \\
\hline Electrical machinery and apparatus n.e.c. (31) & 113 & 37.54 & 0.014 & 0.082 \\
\hline Medical, precision and optical instruments, watches and clocks (33) & 97 & 45.16 & 0.046 & 0.138 \\
\hline Motor vehicles, trailers and semi-trailers (34) & 85 & 25.08 & 0.008 & 0.056 \\
\hline Other transport equipment (35) & 34 & 32.07 & 0.001 & 0.067 \\
\hline $\begin{array}{l}\text { Manufacturing n.e.c.; coke, refined petroleum products and nuclear fuel; } \\
\text { tobacco products }(36,37,23,16)\end{array}$ & 310 & 18.38 & 0.016 & 0.065 \\
\hline
\end{tabular}

Source: Author's calculation from CIP dataset, 1991-2007

Due to CSO confidentiality policy, the following industries with 2-digit NACE Rev.1.1 codes are aggregated: Wearing Apparel; Leather and Leather Products $(18,19)$. Office Machinery and Computers; Radio, Television and Communication Equipment and Apparatus (30, 32). Manufacturing n.e.c.; Coke, Refined Petroleum Products and Nuclear Fuel; Tobacco Products (36, 37, 23, 16)

consisting of firm-characteristic, firm strategy and macroeconomic variables; and $\varepsilon_{i, t}$ is the disturbance term. We include a squared size term to take account of the possible non-linear relationship between initial firm size and growth and to avoid biased estimates resulting from misspecification error (Bigsten and Gebreeyesus 2007).

Given that potential endogeneity may arise from interactions between the three sets of determining factors (firm characteristics, firm strategy and the macroeconomic environment) and firm growth as previously discussed in Sect. 2, we apply the two-stage least squares (2SLS) regression method in testing for endogeneity, where lagged values of the potentially endogenous explanatory variables (e.g. R\&D, export, import, training and the macroeconomic variables) are used as instruments. The Hausman test is employed to test for endogeneity of the strategy and macroeconomic variables both individually and jointly. In all cases, the null hypothesis, in which the variables are exogenous, is rejected (at the 5\% significance level, the critical chisquare values for employment, turnover and productivity growth are 125.46, 638.69 and 230.11 respectively). The $F$-statistics from the first stage confirm the relevance of the instruments. These results indicate the endogeneity of all the strategy and macroeconomic variables, both individually and jointly, in the three growth models. Furthermore, Granger causality tests of the training and trade variables indicate a two-way causal relationship between these strategies and all three measures of firm growth.

Several techniques, including fixed effects, simultaneous equations and instrumental variable methods have been employed in dealing with the endogeneity problem. Following other recent studies (e.g. Nunes et al. 2013a), we use the SYS-GMM estimation method to deal with the potential endogeneity of some 
regressors referred to above. This estimation approach supports the inclusion of time-invariant determinants and remains robust in the presence of autocorrelation and heteroskedasticity, producing unbiased, efficient and consistent estimates (Roodman 2009a). ${ }^{7}$ It also allows the selection of instruments from within the model, using lags of explanatory variables as instruments. We estimate alternative specifications of all firm growth models with different lags of the endogenous variables as instruments. ${ }^{8}$ Additionally, to minimise instrument proliferation, which may potentially reduce the consistency of results, we experiment with collapsing the instruments matrix (Roodman 2009b). The Hansen test is used to assess the validity of the instruments used, and we also test for second-order serial correlation.

\section{Empirical findings}

We begin by discussing the findings for our estimated turnover and employment growth models, followed by those for productivity growth. First, we examine firm growth over the whole period, 1991-2007. We then truncate this time period to consider structural breaks in the data between the two sub-periods, 1991-2000 and 2001-2007, to take account of the two distinct growth phases. We test the sensitivity of our findings by repeating our analyses for sub-samples of firms (e.g. by technology intensity and different entry and exit categories of firms). These results are presented in Tables 9, 10, 11, 12, 13, and 14 in the Appendix.

\footnotetext{
${ }_{7}^{7}$ It is important to acknowledge the possible presence of unobserved time-invariant firm factors (fixed effects) which may be correlated with the explanatory variables in our model. We also estimate fixed effects models to control for unobserved heterogeneity (firm differences) for all firm performance specifications. Results are broadly similar to the SYS-GMM models and are available on request from the authors.

${ }^{8}$ In selecting valid instruments for the growth models, firm size is assumed to be endogenous (due to possible correlation between the firm's size in the previous period and its growth in the current period), and various lag lengths from the second lag are experimented with. In contrast, strategy variables such as R\&D intensity are assumed to be predetermined. For instance, a firm's past and current growth in turnover, employment or productivity may not necessarily be driven by its level of productivity and the amount invested in R\&D in the current period. These may, however, influence its future growth. Based on the Hansen test result, reported results are based on the use of the first three lags of the variables as instruments.
}

4.1 Internal determinants of turnover and employment growth

Table 6 presents our SYS-GMM results for the whole period 1991-2007 and for the two discrete growth phases-1991-2000 and 2001-2007.

\subsubsection{Firm characteristics}

Most of our results confirm our hypotheses. Consistent with Daunfeldt and Elert (2013) and Mazzucato and Parris (2015), we observe an inverse firm size-growth relationship. A $1 \%$ increase in firm size is associated with a 0.09 and $0.13 \%$ decline in turnover and employment growth respectively - evidence that smaller firms experience higher employment and turnover growth. This growth effect declines with increased size, as demonstrated by the positive coefficient on the squared size term. The effect of the initial level of productivity varied with the firm performance measure used. We find a negative effect for this determinant on turnover growth, suggesting a convergence effect. Hence, firms entering the industry with low productivity levels have to increase output quickly to reach the industry MES to avoid failure. By contrast, the positive labour productivity coefficient in the employment growth model provides evidence that firms with higher initial levels of productivity grow faster than less productive firms, consistent with Jovanovic's (1982) model of passive learning, which posits that firms only gain knowledge of their true efficiency after entry into a given industry, and they adjust their sizes accordingly. Given that we measure productivity in terms of turnover per employee, the results above may be driven by endogeneity. However, our endogeneity testing implies the absence of a systematic relationship. ${ }^{9}$ As expected, the positive industry growth variable indicates that firms located in fast growing industries showed faster employment and turnover growth, implying a low competition effect and the availability of more opportunities in these industries (Delmar and Wennberg 2010).

\subsubsection{Firm strategy}

Our results suggest that trade drives manufacturing turnover growth. Two-way traders (i.e. both exporting

\footnotetext{
${ }^{9}$ We test for endogeneity using the Granger causality test.
} 
Table 6 Determinants of turnover and employment growth

\begin{tabular}{|c|c|c|c|c|c|c|}
\hline & \multicolumn{3}{|c|}{ Turnover growth } & \multicolumn{3}{|c|}{ Employment growth } \\
\hline & $\begin{array}{l}\text { 1991-2007 } \\
\text { I }\end{array}$ & $\begin{array}{l}1991-2000 \\
\text { II }\end{array}$ & $\begin{array}{l}2001-2007 \\
\text { III }\end{array}$ & $\begin{array}{l}\text { 1991-2007 } \\
\text { IV }\end{array}$ & $\begin{array}{l}1991-2000 \\
\mathrm{~V}\end{array}$ & $\begin{array}{l}2001-2007 \\
\text { VI }\end{array}$ \\
\hline Log turnover $_{t-1}$ & $\begin{array}{l}-0.095^{* * * *} \\
(0.010)\end{array}$ & $\begin{array}{l}-0.110^{* * *} \\
(0.012)\end{array}$ & $\begin{array}{l}-0.130^{* * * *} \\
(0.019)\end{array}$ & & & \\
\hline$\left(\text { Log turnover } \text { t }_{t-1}\right)^{2}$ & $\begin{array}{l}0.021 * * * \\
(0.002)\end{array}$ & $\begin{array}{l}0.024 * * * \\
(0.003)\end{array}$ & $\begin{array}{l}0.023 * * * \\
(0.003)\end{array}$ & & & \\
\hline Log employment $t_{t-1}$ & & & & $\begin{array}{l}-0.134 * * * \\
(0.008)\end{array}$ & $\begin{array}{l}-0.131 * * * \\
(0.012)\end{array}$ & $\begin{array}{l}-0.166^{* * *} \\
(0.013)\end{array}$ \\
\hline$(\text { Log employment } t-1)^{2}$ & & & & $\begin{array}{l}0.016 * * * \\
(0.001)\end{array}$ & $\begin{array}{l}0.014 * * * \\
(0.002)\end{array}$ & $\begin{array}{l}0.021 * * * \\
(0.002)\end{array}$ \\
\hline Log labour productivity ${ }_{t-1}$ & $\begin{array}{l}-0.160 \text { *** } \\
(0.008)\end{array}$ & $\begin{array}{l}-0.162 * * * \\
(0.010)\end{array}$ & $\begin{array}{l}-0.145^{* * * *} \\
(0.012)\end{array}$ & $\begin{array}{l}0.049 * * * \\
(0.003)\end{array}$ & $\begin{array}{l}0.052 * * * \\
(0.004)\end{array}$ & $\begin{array}{l}0.046^{* * * *} \\
(0.004)\end{array}$ \\
\hline Industry growth & $\begin{array}{l}0.221 * * * \\
(0.013)\end{array}$ & $\begin{array}{l}0.130 * * * \\
(0.025)\end{array}$ & $\begin{array}{l}0.082 * * * \\
(0.014)\end{array}$ & $\begin{array}{l}0.044 * * * \\
(0.007)\end{array}$ & $\begin{array}{l}0.040 * * * \\
(0.014)\end{array}$ & $\begin{array}{l}0.009 \\
(0.010)\end{array}$ \\
\hline Minimum efficient scale & $\begin{array}{l}-0.000 \text { *** } \\
(0.000)\end{array}$ & $\begin{array}{l}0.001 * * * \\
(0.000)\end{array}$ & $\begin{array}{l}-0.000 \\
(0.000)\end{array}$ & $\begin{array}{l}-0.000^{* * *} \\
(0.000)\end{array}$ & $\begin{array}{l}0.000 * * \\
(0.000)\end{array}$ & $\begin{array}{l}-0.000 * \\
(0.000)\end{array}$ \\
\hline Industry concentration & $\begin{array}{l}-0.005 \\
(0.034)\end{array}$ & $\begin{array}{l}-0.861 * * * \\
(0.308)\end{array}$ & $\begin{array}{l}-0.028 \\
(0.059)\end{array}$ & $\begin{array}{l}-0.034 \\
(0.023)\end{array}$ & $\begin{array}{l}-0.513 * * * \\
(0.174)\end{array}$ & $\begin{array}{l}0.025 \\
(0.044)\end{array}$ \\
\hline Nationality of ownership & $\begin{array}{l}0.011 \\
(0.008)\end{array}$ & $\begin{array}{l}0.023 * * \\
(0.010)\end{array}$ & $\begin{array}{l}-0.014 \\
(0.011)\end{array}$ & $\begin{array}{l}0.004 \\
(0.005)\end{array}$ & $\begin{array}{l}0.010 \\
(0.006)\end{array}$ & $\begin{array}{l}-0.002 \\
(0.007)\end{array}$ \\
\hline Export & $\begin{array}{l}0.048^{* * * *} \\
(0.009)\end{array}$ & $\begin{array}{l}0.048 * * * \\
(0.012)\end{array}$ & $\begin{array}{l}0.038 * * * \\
(0.013)\end{array}$ & $\begin{array}{l}-0.008 \\
(0.006)\end{array}$ & $\begin{array}{l}-0.004 \\
(0.008)\end{array}$ & $\begin{array}{l}-0.012 \\
(0.008)\end{array}$ \\
\hline Import & $\begin{array}{l}0.029 * * * \\
(0.006)\end{array}$ & $\begin{array}{l}-0.008 \\
(0.009)\end{array}$ & $\begin{array}{l}0.081 * * * \\
(0.009)\end{array}$ & $\begin{array}{l}-0.008^{* * *} \\
(0.004)\end{array}$ & $\begin{array}{l}-0.016^{* * *} \\
(0.005)\end{array}$ & $\begin{array}{l}-0.003 \\
(0.006)\end{array}$ \\
\hline Export-import & $\begin{array}{l}0.071 * * * \\
(0.007)\end{array}$ & $\begin{array}{l}0.056 * * * \\
(0.009)\end{array}$ & $\begin{array}{l}0.090 * * * \\
(0.010)\end{array}$ & $\begin{array}{l}-0.006^{*} \\
(0.004)\end{array}$ & $\begin{array}{l}-0.004 \\
(0.005)\end{array}$ & $\begin{array}{l}-0.014 * * * \\
(0.005)\end{array}$ \\
\hline Training & $\begin{array}{l}0.020^{* * * *} \\
(0.004)\end{array}$ & $\begin{array}{l}-0.019 * * * \\
(0.006)\end{array}$ & $\begin{array}{l}0.074 * * * \\
(0.007)\end{array}$ & $\begin{array}{l}0.013 * * * \\
(0.002)\end{array}$ & $\begin{array}{l}-0.018 * * * \\
(0.004)\end{array}$ & $\begin{array}{l}0.048 * * * \\
(0.004)\end{array}$ \\
\hline Subsidies & $\begin{array}{l}0.004 \\
(0.005)\end{array}$ & $\begin{array}{l}-0.011 \\
(0.007)\end{array}$ & $\begin{array}{l}0.048 * * * \\
(0.008)\end{array}$ & $\begin{array}{l}0.004 \\
(0.003)\end{array}$ & $\begin{array}{l}0.006 \\
(0.004)\end{array}$ & $\begin{array}{l}-0.007 \\
(0.006)\end{array}$ \\
\hline $\mathrm{R} \& \mathrm{D}$ & $\begin{array}{l}0.044 * * * \\
(0.004)\end{array}$ & $\begin{array}{l}0.020 * * * \\
(0.006)\end{array}$ & $\begin{array}{l}0.065 * * * \\
(0.006)\end{array}$ & $\begin{array}{l}0.004 \\
(0.003)\end{array}$ & $\begin{array}{l}0.003 \\
(0.004)\end{array}$ & $\begin{array}{l}0.007 * \\
(0.004)\end{array}$ \\
\hline $\mathrm{R} \& \mathrm{D}$ intensity & $\begin{array}{l}-0.000^{* * * *} \\
(0.000)\end{array}$ & $\begin{array}{l}-0.000 * * * \\
(0.000)\end{array}$ & $\begin{array}{l}0.003 * * \\
(0.001)\end{array}$ & $\begin{array}{l}-0.000 * * * \\
(0.000)\end{array}$ & $\begin{array}{l}-0.000 * * \\
(0.000)\end{array}$ & $\begin{array}{l}-0.000 \\
(0.000)\end{array}$ \\
\hline Unemployment & $\begin{array}{l}0.003 * * * \\
(0.001)\end{array}$ & $\begin{array}{l}0.027 * * * \\
(0.004)\end{array}$ & $\begin{array}{l}0.089 * * \\
(0.045)\end{array}$ & $\begin{array}{l}0.005 * * * \\
(0.001)\end{array}$ & $\begin{array}{l}0.006^{* *} \\
(0.003)\end{array}$ & $\begin{array}{l}0.034 \\
(0.027)\end{array}$ \\
\hline Inflation & $\begin{array}{l}0.020 * * * \\
(0.002)\end{array}$ & $\begin{array}{l}0.051 * * * \\
(0.004)\end{array}$ & $\begin{array}{l}-0.023 * * * \\
(0.006)\end{array}$ & $\begin{array}{l}-0.009^{* * *} \\
(0.001)\end{array}$ & $\begin{array}{l}-0.006^{* *} \\
(0.002)\end{array}$ & $\begin{array}{l}-0.005 \\
(0.004)\end{array}$ \\
\hline Real effective exchange rate & $\begin{array}{l}-0.002 * * * \\
(0.001)\end{array}$ & $\begin{array}{l}-0.013 * * * \\
(0.001)\end{array}$ & $\begin{array}{l}0.002 \\
(0.002)\end{array}$ & $\begin{array}{l}-0.001 * * * \\
(0.000)\end{array}$ & $\begin{array}{l}-0.001 \\
(0.001)\end{array}$ & $\begin{array}{l}-0.000 \\
(0.002)\end{array}$ \\
\hline Credit & $\begin{array}{l}0.002 * * * \\
(0.000)\end{array}$ & $\begin{array}{l}0.004 * * * \\
(0.001)\end{array}$ & $\begin{array}{l}0.000 \\
(0.000)\end{array}$ & $\begin{array}{l}0.000 * * \\
(0.000)\end{array}$ & $\begin{array}{l}0.001 * \\
(0.000)\end{array}$ & $\begin{array}{l}0.000 \\
(0.000)\end{array}$ \\
\hline Constant & $\begin{array}{l}-0.007 \\
(0.039)\end{array}$ & $\begin{array}{l}0.385 * * * \\
(0.095)\end{array}$ & $\begin{array}{l}-0.406^{* * * *} \\
(0.070)\end{array}$ & $\begin{array}{l}0.360 * * * \\
(0.027)\end{array}$ & $\begin{array}{l}0.216^{* * *} \\
(0.066)\end{array}$ & $\begin{array}{l}0.154 * * * \\
(0.048)\end{array}$ \\
\hline
\end{tabular}


Table 6 (continued)

\begin{tabular}{|c|c|c|c|c|c|c|}
\hline & \multicolumn{3}{|c|}{ Turnover growth } & \multicolumn{3}{|c|}{ Employment growth } \\
\hline & $\begin{array}{l}\text { 1991-2007 } \\
\text { I }\end{array}$ & $\begin{array}{l}1991-2000 \\
\text { II }\end{array}$ & $\begin{array}{l}2001-2007 \\
\text { III }\end{array}$ & $\begin{array}{l}\text { 1991-2007 } \\
\text { IV }\end{array}$ & $\begin{array}{l}1991-2000 \\
\mathrm{~V}\end{array}$ & $\begin{array}{l}2001-2007 \\
\text { VI }\end{array}$ \\
\hline Observations & 59,378 & 32,570 & 26,808 & 59,256 & 32,513 & 26,743 \\
\hline$F$ test & 56.83 & 74.77 & 16.51 & 34.25 & 17.57 & 17.15 \\
\hline Number of firms & 7876 & 5586 & 5833 & 7860 & 5574 & 5811 \\
\hline Hansen test & $3.452(0.33)$ & $3.207(0.36)$ & $2.937(0.40)$ & $0.383(0.54)$ & $3.159(0.37)$ & $2.864(0.41)$ \\
\hline $\mathrm{m} 1$ & -14.89 & -12.40 & -8.470 & -29.37 & -22.92 & -19.58 \\
\hline $\mathrm{m} 2$ & 1.646 & 1.765 & 1.127 & 0.785 & 1.990 & 1.863 \\
\hline Instruments & 46 & 46 & 46 & 44 & 46 & 46 \\
\hline
\end{tabular}

Robust standard errors are in parentheses. $\mathrm{m} 1$ and $\mathrm{m} 2$ are the tests for first- and second-order serial correlation in the first-differenced residuals, asymptotically distributed as $N(0,1)$ under the null of no serial correlation. Values in parentheses represent the $p$ values for the Hansen test and $F$ test. Estimates include industry and location dummies

*Significant at $10 \%$; **significant at $5 \%$; ***significant at $1 \%$

and importing) increased turnover growth by $7 \%$ on average. Vogel and Wagner (2010) and Haller (2012) similarly found a trade premium for two-way traders for manufacturing firms in Germany and Ireland respectively. Importing provides SMEs with access to better quality intermediate goods, while exporting offers access to global markets. Consequently, two-way traders benefit from exporting and importing concurrently.

In contrast to the above, we found that firms engaged in importing and two-way trade experienced decreased employment growth by 0.8 and $0.6 \%$ respectively. Here, it is likely that traders typically use less labour intensive production processes. The import/export story is particularly interesting given the SME make-up of the Irish economy. Indeed, as indicated previously, the sample period was one of exceptional economic performance driven by a rapid growth in exports and a large inflow of foreign direct investment (FDI), particularly in the first growth phase (Ó Riain 2004).

There are mixed results between the firm performance measures used in relation to the effects of the $\mathrm{R} \& \mathrm{D}$ variables. As expected, turnover growth was, on average, positively associated with the firm's R\&D investment decision - firms which invested in R\&D experienced a $4 \%$ increase in turnover growth relative to non-R\&D-active firms. Beginning from 2003, the Department of Jobs, Enterprise and Innovation (2015) notes a significant increase in business expenditure on $R \& D$ and in the number of R\&D-active firms in Ireland. We also find that the magnitude of $R \& D$ investment matters for SME performance. Interestingly, results show that turnover and employment growth decline with $R \& D$ intensity. High risks associated with innovative activity may cause poor SME performance when large investments in R\&D do not yield commercial success (Nunes et al. 2013a). It should be noted, however, that the impact of R\&D intensity on firm growth, though statistically significant, is not quantitatively large in this study. Also, training had a positive effect on employment and turnover performance for the whole sample period, although this finding differs between the two sub-periods.

4.2 External determinants of employment and turnover growth: macroeconomic environment

We find that the macroeconomic environment matters for employment and turnover growth. Specifically, a significant positive effect was found between aggregate unemployment and SME growth for the 1991-2007 sample period - a $1 \%$ increase in the unemployment rate increased employment and turnover growth by 0.5 and $0.3 \%$ respectively. In contrast, inflation had a negative effect on employment growth (a $1 \%$ increase in retail price inflation was associated with a $0.9 \%$ decrease in employment growth) for the whole period. Interestingly, inflation was positively associated with turnover growth (a $1 \%$ increase in inflation leads to a $2 \%$ increase in turnover growth). There was a sharp decline in real interest rates after 1996, with real interest rates becoming negative from 1998; real interest rates in the years 1998-2007 averaged minus 1\% (Dineen et al. 
2012). Lower real interest rates will likely stimulate consumption and investment spending through borrowing, with higher aggregate demand leading to growth in firms' turnover. The positive inflation effect on turnover growth is consistent with Beck et al. (2005) and Mateev and Anastasov (2011). In line with a priori expectations, a rise in the REER index was associated with a decrease in employment and turnover growth. The magnitude of the impact of the REER index on growth was, however, quantitatively small. With respect to domestic credit growth, our results support the hypothesis that the availability of credit promotes turnover growth in manufacturing SMEs, which are commonly financially constrained relative to their larger firm counterparts (Nunes et al. 2013b).

\subsection{Turnover and employment growth across two growth phases}

We now examine whether the drivers of turnover and employment growth vary between the export-led (1991-2000) and credit-led (2001-2007) growth phases. In line with our finding for the whole sample period, we observe a convex firm size-growth relationship across the two sub-periods. The effect of size on firm growth was, however, more pronounced in the credit-led growth phase. Furthermore, the results show that industry growth has a positive effect on employment growth only in the first growth phase, while a smaller effect was found for turnover growth in the second growth phase. This provides further indication of reduced opportunities in manufacturing industries during the latter period. Industry concentration had a dampening effect on turnover and employment growth in the 1991-2000 growth period only. Consistent with our expectations, foreign firms were found to be more likely, on average, to increase turnover (by 2.3\%) than indigenous firms in the 1991-2000 phase - as indicated earlier, the export boom experienced during this subperiod was driven by a strong growth in FDI. Additionally, the impact of firm strategy on turnover and employment growth was conditional on the growth period, where strategies such as trade, training, use of subsidies and R\&D investment had a stronger positive effect on turnover (increasing growth by $9,7.4,4.8$ and $6.5 \%$ respectively) in the 2001-2007 sub-period.

Given that this second growth period was characterised by the loss of international competitiveness in the Irish economy, the results suggest that the aforementioned strategies are more applicable in helping SMEs adjust to adverse changes in the operating environment. The importance of firm strategy for SME growth depends on prevailing macroeconomic conditions - firms adjust their strategies in response to changes in the operating environment which in turn determines subsequent performance. The stronger impact of subsidies on turnover growth observed in this second sub-period may be related to changes to the subsidy regime in response to calls by the European council in 2001 and 2002 for member states to achieve a reduction in state aid from 2003, and to adopt a more targeted approach to state aid, which focuses on horizontal objectives that target identified market failures - that is, training, R\&D and SMEs (European Commission 2002a, b). Buckley and Ruane (2006) also acknowledge that following stricter EU state aid guidelines during this period, the Irish government became more limited in its use of incentives to attract industry, while there was an increase in the provision of subsidies related to training and $R \& D$ expenditure in Ireland.

The macroeconomic variables had different determining effects on firm performance across the two growth phases. Similar to the finding for the whole period, inflation had a positive effect on turnover growth in the export-led growth period, while a dampening effect was observed in the credit-led growth phase. As expected, a negative inflation effect was found for employment growth in the first growth phase. Unemployment had a positive impact on turnover growth in both growth periods, while this positive effect was observed for employment growth in the 1991-2000 period only. During the second growth phase, Ireland experienced a sharp loss of competitiveness as domestic inflation and unit labour costs steadily increased (Honohan 2010), thus manufacturing SME turnover growth was considerably weaker. The dampening effect of a higher pool of unemployed workers on wage growth was missing while the domestic boom continued and close to full aggregate employment was maintained. We find a positive, quantitatively small, credit effect for employment and turnover growth in the 1991-2000 period only. As expected, a decline in competitiveness is associated with lower SME growth. Although generally falling during the 1990s, Ireland's REER index increased more than that of any other country in the euro area from 1999 to 2008 (Regling and Watson 2010). A rise in the REER index makes exports more expensive, and we found a negative relationship between this competitiveness 
indicator and SME manufacturing turnover growth in the 1991-2000 sub-period.

\subsection{Determinants of productivity growth}

To test the sensitivity of productivity growth to different size measures, log employment and log turnover are used in alternate specifications. This approach is motivated by the fact that productivity (turnover per employee) consists of two components: turnover (output) and employment (input). Thus, the alternate use of employment and turnover size variables is important, given that these not only capture different aspects of the firm but may also reflect different strategies adopted by the firm in achieving improved productivity performance. Estimation results are presented in Table 7 .

An inverse firm size effect was found in the turnover size model, suggesting convergence effects, while a positive relation was found in the employment size model (evidence of increasing returns) (Table 7). Again, the size-growth relationship was found to be non-linear as indicated by the significant coefficients on the squared size terms. A convergence effect was also observed for the initial level of productivity in both size models - indicating that firms with lower levels of productivity showed faster growth. Additionally, we find that industry growth has a growth-enhancing effect on productivity for both size specifications. The positive industry growth effect ranged from 7 to $17.7 \%$ across size specifications and growth periods.

The effects of some other determining variables, such as nationality of ownership and the use of subsidies, are sensitive to the size measure used. Foreign-owned firms showed higher productivity growth relative to indigenous firms in the employment size model across all growth periods. However, the observed large productivity differentials between foreign and indigenous firms in Ireland has frequently been attributed, at least in part, to transfer pricing practices adopted by foreign firms in order to take advantage of the low corporation tax rate prevailing in Ireland (Arora and Gambardella 2005). Strategies such as training and the use of subsidies had a positive effect on productivity growth in both size models for the 2001-2007 sub-period only, while a positive R\&D effect was found in both size models across both growth phases. Also, trade matters for productivity growth, with a growth premium ranging from 5 to $8.5 \%$ found for two-way traders in both size models across all periods. The effects of the macroeconomic determinants were consistent across both size measures. Divergent effects were, however, observed across the two discrete growth phases.

Overall, it is important to note that the effects of variables such as firm size, the initial level of productivity, industry growth, exporting, two-way trade and R\&D remained significant, regardless of the sample period and the size measure adopted. This suggests that the firm's starting point, in terms of size and productivity, investment in trade activities (specifically two-way trade and exporting) and the prevailing industry growth rate are important drivers of subsequent productivity growth, confirming findings from other studies (e.g. Caglayan and Demir 2014).

Next, we compare the effects of the determinants across our three growth measures - this reveals some similarities. We find an inverse size-growth effect across all growth indicators, with the largest effect found for employment growth. However, the size definition used in the analysis of productivity growth is important, as we only find a positive size-productivity growth effect for the employment-size model. Industry growth had a positive effect on all growth measures with the largest effect seen for turnover growth. Additionally, our results show a trade effect, with a positive two-way trade premium found for turnover and productivity growth, while trade was observed to hamper employment growth. Also, while we find a positive training effect for all growth indicators, this is dependent on the growth period. In relation to the macroeconomic variables, credit growth was found to have a positive, albeit small effect on all firm growth measures. Again, the effect is dependent on the time period.

We assess the robustness of our findings as follows: First, we repeat the analyses of employment and turnover growth across sub-samples of firms classified by technology intensity (high-tech versus low-tech). Second, in order to clarify potential problems of survival bias in the sample, we constrain our firm growth analyses for the whole period and sub-periods to (i) SMEs that remained in the sample during the period; (ii) SMEs that entered the sample during the period; (iii) SMEs that left the sample during the period; and (iv) SMEs that ceased to be so during the period (i.e. SMEs that left the sample due to becoming large firms). It is important to know if the firms in the sub-period, 1991-2000, are/ are not included in the second growth phase, 20012007. The robustness tests, thus, provide another layer of analysis which shows how the determining variables 
Table 7 Determinants of productivity growth

\begin{tabular}{|c|c|c|c|c|c|c|}
\hline & \multicolumn{6}{|c|}{ Productivity growth } \\
\hline & \multicolumn{3}{|c|}{ Size (Turnover) } & \multicolumn{3}{|c|}{ Size (Employment) } \\
\hline & $\begin{array}{l}\text { 1991-2007 } \\
\text { I }\end{array}$ & $\begin{array}{l}\text { 1991-2000 } \\
\text { II }\end{array}$ & $\begin{array}{l}\text { 2001-2007 } \\
\text { III }\end{array}$ & $\begin{array}{l}\text { 1991-2007 } \\
\text { IV }\end{array}$ & $\begin{array}{l}1991-2000 \\
V\end{array}$ & $\begin{array}{l}\text { 2001-2007 } \\
\text { VI }\end{array}$ \\
\hline Log turnover $_{t-1}$ & $\begin{array}{l}-0.049 * * * \\
(0.009)\end{array}$ & $\begin{array}{l}-0.058^{* * * *} \\
(0.012)\end{array}$ & $\begin{array}{l}-0.069^{* * *} \\
(0.017)\end{array}$ & & & \\
\hline$\left(\text { Log turnover }{ }_{t-1}\right)^{2}$ & $\begin{array}{l}0.020^{* * * *} \\
(0.002)\end{array}$ & $\begin{array}{l}0.023 * * * \\
(0.002)\end{array}$ & $\begin{array}{l}0.021 * * * \\
(0.003)\end{array}$ & & & \\
\hline Log employment $t_{-1}$ & & & & $\begin{array}{l}0.138 * * * \\
(0.011)\end{array}$ & $\begin{array}{l}0.170 * * * \\
(0.015)\end{array}$ & $\begin{array}{l}0.107 * * * \\
(0.015)\end{array}$ \\
\hline$(\text { Log employment } t-1)^{2}$ & & & & $\begin{array}{l}-0.014^{* * * *} \\
(0.002)\end{array}$ & $\begin{array}{l}-0.019 * * * \\
(0.002)\end{array}$ & $\begin{array}{l}-0.010^{* * *} \\
(0.002)\end{array}$ \\
\hline Log labour productivity $_{t-1}$ & $\begin{array}{l}-0.253 * * * \\
(0.007)\end{array}$ & $\begin{array}{l}-0.261 * * * \\
(0.010)\end{array}$ & $\begin{array}{l}-0.245^{* * *} \\
(0.012)\end{array}$ & $\begin{array}{l}-0.203^{* * *} \\
(0.008)\end{array}$ & $\begin{array}{l}-0.210 * * * \\
(0.010)\end{array}$ & $\begin{array}{l}-0.197 * * * \\
(0.013)\end{array}$ \\
\hline Industry growth & $\begin{array}{l}0.177 * * * \\
(0.012)\end{array}$ & $\begin{array}{l}0.092 * * * \\
(0.022)\end{array}$ & $\begin{array}{l}0.073 * * * \\
(0.014)\end{array}$ & $\begin{array}{l}0.166^{* * * *} \\
(0.012)\end{array}$ & $\begin{array}{l}0.084 * * * \\
(0.022)\end{array}$ & $\begin{array}{l}0.070 * * * \\
(0.014)\end{array}$ \\
\hline Minimum efficient scale & $\begin{array}{l}-0.000 * * \\
(0.000)\end{array}$ & $\begin{array}{l}0.001 * * \\
(0.000)\end{array}$ & $\begin{array}{l}-0.000 \\
(0.000)\end{array}$ & $\begin{array}{l}0.000 \\
(0.000)\end{array}$ & $\begin{array}{l}0.001 * * * \\
(0.000)\end{array}$ & $\begin{array}{l}0.000 \\
(0.000)\end{array}$ \\
\hline Industry concentration & $\begin{array}{l}0.025 \\
(0.032)\end{array}$ & $\begin{array}{l}-0.394 \\
(0.292)\end{array}$ & $\begin{array}{l}-0.026 \\
(0.058)\end{array}$ & $\begin{array}{l}0.001 \\
(0.031)\end{array}$ & $\begin{array}{l}-0.354 \\
(0.293)\end{array}$ & $\begin{array}{l}-0.046 \\
(0.057)\end{array}$ \\
\hline Nationality of ownership & $\begin{array}{l}0.003 \\
(0.007)\end{array}$ & $\begin{array}{l}0.014 \\
(0.009)\end{array}$ & $\begin{array}{l}-0.020^{*} \\
(0.011)\end{array}$ & $\begin{array}{l}0.050 * * * \\
(0.008)\end{array}$ & $\begin{array}{l}0.059 * * * \\
(0.010)\end{array}$ & $\begin{array}{l}0.039 * * * \\
(0.011)\end{array}$ \\
\hline Export & $\begin{array}{l}0.048 * * * \\
(0.009)\end{array}$ & $\begin{array}{l}0.046 * * * \\
(0.013)\end{array}$ & $\begin{array}{l}0.042 * * * \\
(0.012)\end{array}$ & $\begin{array}{l}0.054 * * * \\
(0.010)\end{array}$ & $\begin{array}{l}0.067 * * * \\
(0.014)\end{array}$ & $\begin{array}{l}0.040 * * * \\
(0.012)\end{array}$ \\
\hline Import & $\begin{array}{l}0.029 * * * \\
(0.006)\end{array}$ & $\begin{array}{l}0.002 \\
(0.009)\end{array}$ & $\begin{array}{l}0.074 * * * \\
(0.008)\end{array}$ & $\begin{array}{l}0.034 * * * \\
(0.006)\end{array}$ & $\begin{array}{l}0.014 \\
(0.009)\end{array}$ & $\begin{array}{l}0.064 * * * \\
(0.008)\end{array}$ \\
\hline Export-import & $\begin{array}{l}0.065^{* * * *} \\
(0.006)\end{array}$ & $\begin{array}{l}0.050 * * * \\
(0.009)\end{array}$ & $\begin{array}{l}0.085^{* * * *} \\
(0.009)\end{array}$ & $\begin{array}{l}0.072 * * * \\
(0.006)\end{array}$ & $\begin{array}{l}0.063 * * * \\
(0.009)\end{array}$ & $\begin{array}{l}0.082^{* * * *} \\
(0.008)\end{array}$ \\
\hline Training & $\begin{array}{l}0.003 \\
(0.004)\end{array}$ & $\begin{array}{l}-0.010 \\
(0.006)\end{array}$ & $\begin{array}{l}0.023 * * * \\
(0.007)\end{array}$ & $\begin{array}{l}0.023 * * * \\
(0.004)\end{array}$ & $\begin{array}{l}0.027 * * * \\
(0.005)\end{array}$ & $\begin{array}{l}0.020 * * * \\
(0.007)\end{array}$ \\
\hline Subsidies & $\begin{array}{l}-0.001 \\
(0.005)\end{array}$ & $\begin{array}{l}-0.018^{* * * *} \\
(0.006)\end{array}$ & $\begin{array}{l}0.056 * * * \\
(0.009)\end{array}$ & $\begin{array}{l}0.015 * * * \\
(0.005)\end{array}$ & $\begin{array}{l}0.003 \\
(0.006)\end{array}$ & $\begin{array}{l}0.054 * * * \\
(0.009)\end{array}$ \\
\hline $\mathrm{R} \& \mathrm{D}$ & $\begin{array}{l}0.037 * * * \\
(0.004)\end{array}$ & $\begin{array}{l}0.014 * * \\
(0.006)\end{array}$ & $\begin{array}{l}0.057 * * * \\
(0.006)\end{array}$ & $\begin{array}{l}0.038 * * * \\
(0.005)\end{array}$ & $\begin{array}{l}0.027 * * * \\
(0.006)\end{array}$ & $\begin{array}{l}0.046^{* * * *} \\
(0.006)\end{array}$ \\
\hline $\mathrm{R} \& \mathrm{D}$ intensity & $\begin{array}{l}-0.000 * * * \\
(0.000)\end{array}$ & $\begin{array}{l}-0.000^{* * * *} \\
(0.000)\end{array}$ & $\begin{array}{l}0.003 * * \\
(0.001)\end{array}$ & $\begin{array}{l}-0.000^{* * * *} \\
(0.000)\end{array}$ & $\begin{array}{l}-0.000 * * * \\
(0.000)\end{array}$ & $\begin{array}{l}0.003 * * \\
(0.001)\end{array}$ \\
\hline Unemployment & $\begin{array}{l}-0.001 \\
(0.001)\end{array}$ & $\begin{array}{l}0.020 * * * \\
(0.004)\end{array}$ & $\begin{array}{l}0.010 \\
(0.042)\end{array}$ & $\begin{array}{l}-0.001 \\
(0.001)\end{array}$ & $\begin{array}{l}0.023 * * * \\
(0.004)\end{array}$ & $\begin{array}{l}0.026 \\
(0.043)\end{array}$ \\
\hline Inflation & $\begin{array}{l}0.030 * * * \\
(0.002)\end{array}$ & $\begin{array}{l}0.057 * * * \\
(0.003)\end{array}$ & $\begin{array}{l}-0.013 * * \\
(0.006)\end{array}$ & $\begin{array}{l}0.032 * * * \\
(0.002)\end{array}$ & $\begin{array}{l}0.057 * * * \\
(0.003)\end{array}$ & $\begin{array}{l}-0.015^{* *} \\
(0.006)\end{array}$ \\
\hline Real effective exchange rate & $\begin{array}{l}-0.001 * * \\
(0.000)\end{array}$ & $\begin{array}{l}-0.012 * * * \\
(0.001)\end{array}$ & $\begin{array}{l}0.003 \\
(0.002)\end{array}$ & $\begin{array}{l}-0.001 \\
(0.000)\end{array}$ & $\begin{array}{l}-0.012 * * * \\
(0.001)\end{array}$ & $\begin{array}{l}0.003 \\
(0.002)\end{array}$ \\
\hline Credit & $\begin{array}{l}0.001 * * * \\
(0.000)\end{array}$ & $\begin{array}{l}0.004 * * * \\
(0.001)\end{array}$ & $\begin{array}{l}-0.000 \\
(0.000)\end{array}$ & $\begin{array}{l}0.001 * * * \\
(0.000)\end{array}$ & $\begin{array}{l}0.004 * * * \\
(0.001)\end{array}$ & $\begin{array}{l}0.000 \\
(0.000)\end{array}$ \\
\hline
\end{tabular}


Table 7 (continued)

\begin{tabular}{|c|c|c|c|c|c|c|}
\hline & \multicolumn{6}{|c|}{ Productivity growth } \\
\hline & \multicolumn{3}{|c|}{ Size (Turnover) } & \multicolumn{3}{|c|}{ Size (Employment) } \\
\hline & $\begin{array}{l}\text { 1991-2007 } \\
\text { I }\end{array}$ & $\begin{array}{l}\text { 1991-2000 } \\
\text { II }\end{array}$ & $\begin{array}{l}\text { 2001-2007 } \\
\text { III }\end{array}$ & $\begin{array}{l}\text { 1991-2007 } \\
\text { IV }\end{array}$ & $\begin{array}{l}1991-2000 \\
\text { V }\end{array}$ & $\begin{array}{l}\text { 2001-2007 } \\
\text { VI }\end{array}$ \\
\hline Constant & $\begin{array}{l}-0.216^{* * *} \\
(0.035)\end{array}$ & $\begin{array}{l}0.272 * * * \\
(0.091)\end{array}$ & $\begin{array}{l}-0.367 * * * \\
(0.065)\end{array}$ & $\begin{array}{l}-0.468 * * * \\
(0.041)\end{array}$ & $\begin{array}{l}-0.037 \\
(0.095)\end{array}$ & $\begin{array}{l}-0.573 * * * \\
(0.071)\end{array}$ \\
\hline Observations & 59,256 & 32,513 & 26,743 & 59,256 & 32,513 & 26,743 \\
\hline$F$ test & 74.84 & 125 & 20.14 & 1121 & 190.4 & 16.17 \\
\hline Number of firms & 7860 & 5574 & 5811 & 7860 & 5574 & 5811 \\
\hline Hansen test & $3.426(0.33)$ & $3.004(0.39)$ & $2.446(0.49)$ & $0.862(0.35)$ & $3.073(0.38)$ & $2.260(0.52)$ \\
\hline $\mathrm{m} 1$ & -17.96 & -14.44 & -10.37 & -15.93 & -12.61 & -9.387 \\
\hline $\mathrm{m} 2$ & 1.170 & 1.013 & 1.130 & 1.669 & 1.495 & 1.875 \\
\hline Instruments & 46 & 46 & 46 & 44 & 46 & 46 \\
\hline
\end{tabular}

Note: Robust standard errors are in parentheses. $\mathrm{m} 1$ and $\mathrm{m} 2$ are the tests for first- and second-order serial correlation in the first-differenced residuals, asymptotically distributed as $N(0,1)$ under the null of no serial correlation. Values in parentheses represent the $p$ values for the Hansen test and $F$ test. Estimates include industry and location dummies

*Significant at $10 \%$; * significant at 5\%; ***Significant at $1 \%$

interact with firm growth for the different types of firms. The results are broadly similar to our previous findings, and the interested reader should refer to the Appendix to this paper for these results (Tables 9, 10, 11, 12, 13, and 14).

Overall, the results from our analyses - which show interactions between firm characteristics, strategy and the macroeconomic environment-support a holistic modelling approach in studying firm growth. Also, the specific effect of all determining factors of growth varied with the growth measure adopted. Furthermore, the empirical investigation of SME growth across two subperiods, characterised by different growth sources, indicates that the macroeconomic environment not only exerts a direct effect on growth, but it also has a moderating effect on the relationship between firm characteristics, firm strategy and growth. For instance, firm strategies such as trade and training became more important in the credit-led growth phase.

\section{Conclusion}

This paper analyses the determinants of SME growth, using firm-level panel data combined with macroeconomic variables for the period 1991-2007. We make a novel theoretical contribution to the firm performance literature by developing a holistic multivariate modelling approach which not only relates SME performance to firm characteristics, firm strategy and the macroeconomic environment but also considers multiple firm growth measures (employment, turnover and productivity). This study investigates firm performance across two distinct growth phases in Ireland-an export-led boom (1991-2000) and a credit-fuelled domestic demand-driven boom (2001-2007) —and provides much needed empirical evidence, adding to the sparse literature on the relationship between SME performance and prevailing macroeconomic conditions.

Our empirical analysis leads to three broad conclusions. First, we find that the macroeconomic environment influences SME growth directly-SMEs showed higher growth when aggregate output growth was stronger in the first growth phase. Second, the use of a holistic framework which integrates the internal and external growth drivers reveals an indirect macroeconomic effect on firm growth. Our results show that SMEs adjust their strategies in response to changes in the operating environment, with the positive effect of strategies such as training, $\mathrm{R} \& \mathrm{D}$ and trade becoming more pronounced in the more challenging macroeconomic conditions faced by manufacturing firms during the 2001-2007 period. Moreover, results suggest 
possible interactions between the determining factors and the firm growth. For instance, we find evidence of the endogeneity of the firm strategy and macroeconomic variables, as detailed previously in Sects. 2.2 and 3.2. Third, using multiple measures of firm growth, we observe heterogeneity in SME performance across the two discrete macroeconomic growth phases. We also find that the effect of both the macroeconomic and internal determinants varies with the firm performance measure used.

The overarching insight emerging from this research is that SME growth is driven by a combination of firm characteristics, firm strategy, and macroeconomic conditions. More specifically, we find evidence in support of smaller firms as important sources of employment and turnover growth, consistent with the literature on Gibrat's law. This finding was robust across all model specifications and growth periods. The firm's starting quality in terms of its initial size and initial level of productivity is critical to its subsequent performance. Evidence on the importance of smaller firms in generating jobs and output provides empirical support for the design of more targeted policies to promote SME growth. In terms of strategy, we find evidence that two-way traders have better turnover and productivity performance than firms which export or import only. The policy implication of this finding is that initiatives which support SMEs in sourcing international suppliers may be as important as policies aimed at facilitating their entry into global export markets. Similarly, the firm's decision to invest in $R \& D$ has a positive effect on turnover and productivity growth, while the magnitude of $R \& D$ investment also matters for firm growth. In terms of policy, these results suggest the need for soft support, such as training, to build capacity in SMEs - this would enable firms to maximise the benefits that may be associated with increased investments in R\&D. The finding that training investment boosts SME growth also provides support for further analysis regarding the design of relevant training programmes for SMEs. This research also highlights a potential role for policies aimed at creating favourable macroeconomic conditions, as well as export-oriented policies that promote balanced and sustainable economic growth. All of these are necessary to stimulate SME growth.
There are limitations to our study, which clearly provide avenues for future research. The use of secondary data, while providing a very large number of observations, offers a limited number of variables. The most obvious one is the lack of data relating to other measures of firm performance such as profitability and total factor productivity. The availability of such data would enable empirical testing of the link between macroeconomic conditions and other dimensions of firm performance. Additionally, a lack of data on firm age precludes an investigation of whether, and how macroeconomic effects on SME growth may vary with firm age. Although this analysis of SME performance is situated in an Irish context, our study represents an important contribution in an interesting research area worthy of further exploration in other country contexts. The methodology and analysis have likely applications to similar datasets in other country contexts. Such datasets include the Annual Business Survey conducted by the Office of National Statistics in the UK, and the Structural Business Statistics conducted by Statistics Sweden on an annual basis.

Going forward, we argue that there is a gap in the extant firm growth literature which tends to focus solely on the internal determinants of firm growth. To progress the ongoing debate on the determinants of firm growth, we suggest that both the internal and external drivers (macroeconomic environment) of growth should be considered within a holistic multivariate framework. Applying such a theoretical and modelling approach to firm growth is necessary because the relationship between firm growth and its internal determinants (firm characteristics and firm strategy) is itself moderated by the macroeconomic environment. Moreover, results which suggest the endogeneity of the determining factors of firm growth also provide support for a holistic modelling approach. Although beyond the scope of the current paper, our findings suggest a potential role for policies to support the development of smaller indigenous firms, including initiatives to promote trade, training and R\&D strategies. Additionally, our approach corroborates the importance for policy makers to take account of the multidimensional nature of firm performance through the use of multiple, rather than single growth measures, in assessing performance outcomes in firms. While it is clear that the macroeconomy does influence firm performance, we provide empirical evidence on the channels through which this occurs - thus, addressing both the 'what' and the 'how' of this interaction. 


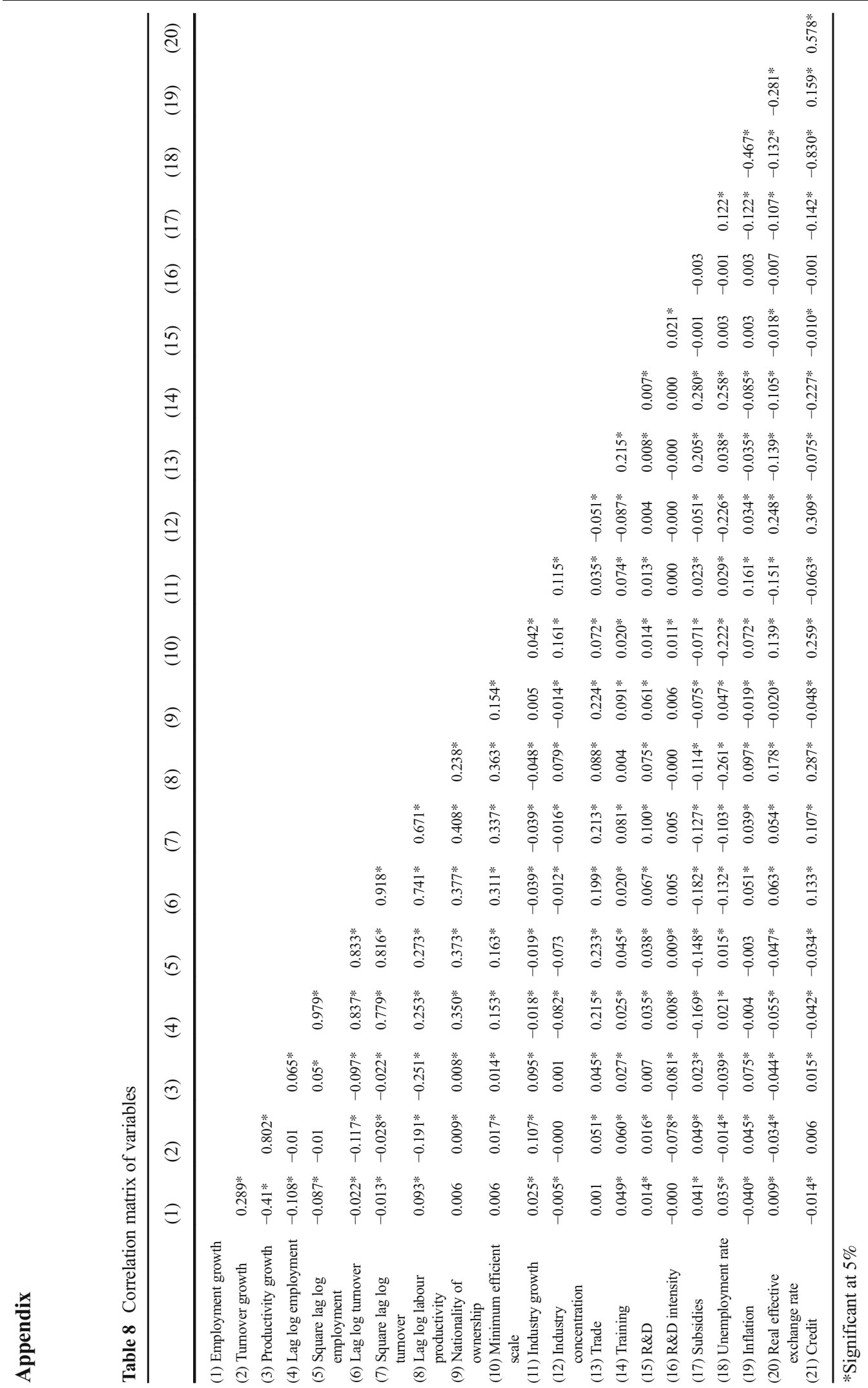


Table 9 Determinants of employment growth by technology intensity

\begin{tabular}{|c|c|c|c|c|c|c|}
\hline & \multicolumn{3}{|l|}{ High-tech } & \multicolumn{3}{|l|}{ Low-tech } \\
\hline & $\begin{array}{l}\text { 1991-2007 } \\
\text { I }\end{array}$ & $\begin{array}{l}\text { 1991-2000 } \\
\text { II }\end{array}$ & $\begin{array}{l}2001-2007 \\
\text { III }\end{array}$ & $\begin{array}{l}\text { 1991-2007 } \\
\text { IV }\end{array}$ & $\begin{array}{l}1991-2000 \\
\text { V }\end{array}$ & $\begin{array}{l}\text { 2001-2007 } \\
\text { VI }\end{array}$ \\
\hline Log employment $t_{t-1}$ & $\begin{array}{l}-0.082 \\
(0.067)\end{array}$ & $\begin{array}{l}-0.207 * \\
(0.118)\end{array}$ & $\begin{array}{l}0.016 \\
(0.037)\end{array}$ & $\begin{array}{l}-0.086^{* * * *} \\
(0.018)\end{array}$ & $\begin{array}{l}-0.062 * * * \\
(0.021)\end{array}$ & $\begin{array}{l}-0.136^{* * *} \\
(0.029)\end{array}$ \\
\hline$\left(\text { Log employment } t_{t-1}\right)^{2}$ & $\begin{array}{l}0.008 \\
(0.011)\end{array}$ & $\begin{array}{l}0.028 \\
(0.019)\end{array}$ & $\begin{array}{l}-0.008 \\
(0.006)\end{array}$ & $\begin{array}{l}0.008 * * \\
(0.003)\end{array}$ & $\begin{array}{l}0.003 \\
(0.004)\end{array}$ & $\begin{array}{l}0.016^{* * * *} \\
(0.005)\end{array}$ \\
\hline Log labour productivity ${ }_{t-1}$ & $\begin{array}{l}0.030 * * * \\
(0.007)\end{array}$ & $\begin{array}{l}0.030 \text { *** } \\
(0.011)\end{array}$ & $\begin{array}{l}0.036^{* * * *} \\
(0.008)\end{array}$ & $\begin{array}{l}0.054 * * * \\
(0.003)\end{array}$ & $\begin{array}{l}0.059 * * * \\
(0.003)\end{array}$ & $\begin{array}{l}0.051 * * * \\
(0.006)\end{array}$ \\
\hline Log labour productivity $_{t-1}$ & $\begin{array}{l}0.008 \\
(0.012)\end{array}$ & $\begin{array}{l}0.014 \\
(0.022)\end{array}$ & $\begin{array}{l}-0.014 \\
(0.015)\end{array}$ & $\begin{array}{l}0.060 * * * \\
(0.008)\end{array}$ & $\begin{array}{l}0.061 * * * \\
(0.016)\end{array}$ & $\begin{array}{l}0.036 * * * \\
(0.011)\end{array}$ \\
\hline Industry growth & $\begin{array}{l}0.000 \\
(0.000)\end{array}$ & $\begin{array}{l}0.000 \\
(0.000)\end{array}$ & $\begin{array}{l}0.000 \\
(0.000)\end{array}$ & $\begin{array}{l}-0.000 * * * \\
(0.000)\end{array}$ & $\begin{array}{l}-0.000 * * * \\
(0.000)\end{array}$ & $\begin{array}{l}-0.000 \\
(0.000)\end{array}$ \\
\hline Minimum efficient scale & $\begin{array}{l}0.012 \\
(0.107)\end{array}$ & $\begin{array}{l}0.106 \\
(0.182)\end{array}$ & $\begin{array}{l}-0.036 \\
(0.125)\end{array}$ & $\begin{array}{l}-0.080 * * * \\
(0.018)\end{array}$ & $\begin{array}{l}-0.380 * * * \\
(0.104)\end{array}$ & $\begin{array}{l}-0.055^{* * * *} \\
(0.019)\end{array}$ \\
\hline Industry concentration & $\begin{array}{l}0.023 * * * \\
(0.009)\end{array}$ & $\begin{array}{l}0.026^{* *} \\
(0.011)\end{array}$ & $\begin{array}{l}0.020 \\
(0.012)\end{array}$ & $\begin{array}{l}0.001 \\
(0.005)\end{array}$ & $\begin{array}{l}0.009 \\
(0.007)\end{array}$ & $\begin{array}{l}-0.009 \\
(0.008)\end{array}$ \\
\hline Nationality of ownership & $\begin{array}{l}0.013 \\
(0.010)\end{array}$ & $\begin{array}{l}0.005 \\
(0.013)\end{array}$ & $\begin{array}{l}0.035 * * \\
(0.014)\end{array}$ & $\begin{array}{l}0.019 * * * \\
(0.004)\end{array}$ & $\begin{array}{l}0.015 * * * \\
(0.005)\end{array}$ & $\begin{array}{l}0.025 * * * \\
(0.006)\end{array}$ \\
\hline Export & $\begin{array}{l}-0.002 \\
(0.011)\end{array}$ & $\begin{array}{l}-0.017 \\
(0.017)\end{array}$ & $\begin{array}{l}-0.003 \\
(0.018)\end{array}$ & $\begin{array}{l}-0.007 * \\
(0.004)\end{array}$ & $\begin{array}{l}-0.012 * * \\
(0.005)\end{array}$ & $\begin{array}{l}-0.002 \\
(0.006)\end{array}$ \\
\hline Import & $\begin{array}{l}0.014 \\
(0.010)\end{array}$ & $\begin{array}{l}0.004 \\
(0.017)\end{array}$ & $\begin{array}{l}0.004 \\
(0.015)\end{array}$ & $\begin{array}{l}-0.008 * * \\
(0.004)\end{array}$ & $\begin{array}{l}-0.000 \\
(0.005)\end{array}$ & $\begin{array}{l}-0.019 \text { *** } \\
(0.005)\end{array}$ \\
\hline Export-import & $\begin{array}{l}0.018 * * * \\
(0.007)\end{array}$ & $\begin{array}{l}-0.024 \\
(0.016)\end{array}$ & $\begin{array}{l}0.049 * * * \\
(0.009)\end{array}$ & $\begin{array}{l}0.014 * * * \\
(0.003)\end{array}$ & $\begin{array}{l}-0.012 * * * \\
(0.004)\end{array}$ & $\begin{array}{l}0.047 * * * \\
(0.005)\end{array}$ \\
\hline Training & $\begin{array}{l}0.024 * * * \\
(0.008)\end{array}$ & $\begin{array}{l}0.024 * * \\
(0.012)\end{array}$ & $\begin{array}{l}0.006 \\
(0.012)\end{array}$ & $\begin{array}{l}-0.000 \\
(0.004)\end{array}$ & $\begin{array}{l}0.003 \\
(0.005)\end{array}$ & $\begin{array}{l}-0.012 \\
(0.007)\end{array}$ \\
\hline Subsidies & $\begin{array}{l}0.008 \\
(0.006)\end{array}$ & $\begin{array}{l}0.005 \\
(0.009)\end{array}$ & $\begin{array}{l}0.009 \\
(0.008)\end{array}$ & $\begin{array}{l}0.005 \\
(0.003)\end{array}$ & $\begin{array}{l}0.004 \\
(0.004)\end{array}$ & $\begin{array}{l}0.005 \\
(0.005)\end{array}$ \\
\hline$R \& D$ & $\begin{array}{l}0.000 \\
(0.000)\end{array}$ & $\begin{array}{l}0.000 \\
(0.000)\end{array}$ & $\begin{array}{l}-0.001 \\
(0.000)\end{array}$ & $\begin{array}{l}-0.000 * * * \\
(0.000)\end{array}$ & $\begin{array}{l}-0.000 * * * \\
(0.000)\end{array}$ & $\begin{array}{l}0.001 * * \\
(0.001)\end{array}$ \\
\hline $\mathrm{R} \& \mathrm{D}$ intensity & $\begin{array}{l}0.007 * * * \\
(0.002)\end{array}$ & $\begin{array}{l}0.009 \\
(0.006)\end{array}$ & $\begin{array}{l}-0.036 \\
(0.055)\end{array}$ & $\begin{array}{l}0.004 * * * \\
(0.001)\end{array}$ & $\begin{array}{l}0.006^{* *} \\
(0.003)\end{array}$ & $\begin{array}{l}0.051 * \\
(0.031)\end{array}$ \\
\hline Unemployment & $\begin{array}{l}-0.009^{* * *} \\
(0.003)\end{array}$ & $\begin{array}{l}-0.002 \\
(0.005)\end{array}$ & $\begin{array}{l}-0.005 \\
(0.009)\end{array}$ & $\begin{array}{l}-0.009 * * * \\
(0.002)\end{array}$ & $\begin{array}{l}-0.006^{* *} \\
(0.003)\end{array}$ & $\begin{array}{l}-0.005 \\
(0.005)\end{array}$ \\
\hline Inflation & $\begin{array}{l}-0.003^{* * * *} \\
(0.001)\end{array}$ & $\begin{array}{l}-0.003 * \\
(0.002)\end{array}$ & $\begin{array}{l}0.002 \\
(0.003)\end{array}$ & $\begin{array}{l}-0.001 * * \\
(0.000)\end{array}$ & $\begin{array}{l}-0.001 \\
(0.001)\end{array}$ & $\begin{array}{l}-0.001 \\
(0.002)\end{array}$ \\
\hline Credit & $\begin{array}{l}0.000 * * \\
(0.000)\end{array}$ & $\begin{array}{l}0.001 \\
(0.001)\end{array}$ & $\begin{array}{l}-0.000 \\
(0.000)\end{array}$ & $\begin{array}{l}0.000 \\
(0.000)\end{array}$ & $\begin{array}{l}0.001 * * \\
(0.000)\end{array}$ & $\begin{array}{l}0.000 \\
(0.000)\end{array}$ \\
\hline Constant & $\begin{array}{l}0.026 \\
(0.097)\end{array}$ & $\begin{array}{l}0.483 * * \\
(0.222)\end{array}$ & $\begin{array}{l}0.030 \\
(0.092)\end{array}$ & $\begin{array}{l}0.266 * * * \\
(0.035)\end{array}$ & $\begin{array}{l}0.169 * * \\
(0.077)\end{array}$ & $\begin{array}{l}0.053 \\
(0.060)\end{array}$ \\
\hline Observations & 11,433 & 6728 & 11,433 & 47,850 & 25,798 & 22,052 \\
\hline$F$ test & 7.752 & 15.85 & 11.84 & 43.42 & 24.07 & 23.12 \\
\hline Number of firms & 1595 & 1240 & 1595 & 6564 & 4469 & 4908 \\
\hline Hansen test & $3.78(0.14)$ & $3.86(0.52)$ & $5.835(0.12)$ & $2.363(0.50)$ & $2.143(0.54)$ & $1.827(0.61)$ \\
\hline
\end{tabular}


Table 9 (continued)

\begin{tabular}{|c|c|c|c|c|c|c|}
\hline & \multicolumn{3}{|l|}{ High-tech } & \multicolumn{3}{|l|}{ Low-tech } \\
\hline & $\begin{array}{l}\text { 1991-2007 } \\
\text { I }\end{array}$ & $\begin{array}{l}\text { 1991-2000 } \\
\text { II }\end{array}$ & $\begin{array}{l}\text { 2001-2007 } \\
\text { III }\end{array}$ & $\begin{array}{l}\text { 1991-2007 } \\
\text { IV }\end{array}$ & $\begin{array}{l}\text { 1991-2000 } \\
\text { V }\end{array}$ & $\begin{array}{l}2001-2007 \\
\text { VI }\end{array}$ \\
\hline $\mathrm{m} 1$ & -9.796 & -7.010 & -10.03 & -26.04 & -19.33 & -17.99 \\
\hline $\mathrm{m} 2$ & 1.973 & 1.900 & 1.849 & 1.827 & 1.455 & 1.605 \\
\hline Instruments & 34 & 34 & 29 & 29 & 29 & 29 \\
\hline
\end{tabular}

Robust standard errors are in parentheses. $\mathrm{m} 1$ and $\mathrm{m} 2$ are the tests for first- and second-order serial correlation in the first-differenced residuals, asymptotically distributed as $N(0,1)$ under the null of no serial correlation. Values in parentheses represent the $p$ values for the Hansen test and $F$ test. Estimates include location dummies

$*$ Significant at $10 \%$;*significant at $5 \%$; ***significant at $1 \%$

Table 10 Determinants of turnover growth by technology intensity

\begin{tabular}{|c|c|c|c|c|c|c|}
\hline & \multicolumn{3}{|l|}{ High-tech } & \multicolumn{3}{|l|}{ Low-tech } \\
\hline & $\begin{array}{l}\text { 1991-2007 } \\
\text { I }\end{array}$ & $\begin{array}{l}\text { 1991-2000 } \\
\text { II }\end{array}$ & $\begin{array}{l}\text { 2001-2007 } \\
\text { III }\end{array}$ & $\begin{array}{l}\text { 1991-2007 } \\
\text { IV }\end{array}$ & $\begin{array}{l}1991-2000 \\
\text { V }\end{array}$ & $\begin{array}{l}2001-2007 \\
\text { VI }\end{array}$ \\
\hline Log turnover ${ }_{t-1}$ & $\begin{array}{l}-0.082 \\
(0.067)\end{array}$ & $\begin{array}{l}-0.207 * \\
(0.118)\end{array}$ & $\begin{array}{l}0.016 \\
(0.037)\end{array}$ & $\begin{array}{l}-0.086^{* * *} \\
(0.018)\end{array}$ & $\begin{array}{l}-0.062^{* * * *} \\
(0.021)\end{array}$ & $\begin{array}{l}-0.136^{* * *} \\
(0.029)\end{array}$ \\
\hline$\left(\text { Log turnover } \text { t }_{t-1}\right)^{2}$ & $\begin{array}{l}0.008 \\
(0.011)\end{array}$ & $\begin{array}{l}0.028 \\
(0.019)\end{array}$ & $\begin{array}{l}-0.008 \\
(0.006)\end{array}$ & $\begin{array}{l}0.008 * * \\
(0.003)\end{array}$ & $\begin{array}{l}0.003 \\
(0.004)\end{array}$ & $\begin{array}{l}0.016 * * * \\
(0.005)\end{array}$ \\
\hline Log labour productivity ${ }_{t-1}$ & $\begin{array}{l}0.030 \text { *** } \\
(0.007)\end{array}$ & $\begin{array}{l}0.030 * * * \\
(0.011)\end{array}$ & $\begin{array}{l}0.036 * * * \\
(0.008)\end{array}$ & $\begin{array}{l}0.054 * * * \\
(0.003)\end{array}$ & $\begin{array}{l}0.059 * * * \\
(0.003)\end{array}$ & $\begin{array}{l}0.051 * * * \\
(0.006)\end{array}$ \\
\hline Log labour productivity ${ }_{t-1}$ & $\begin{array}{l}0.008 \\
(0.012)\end{array}$ & $\begin{array}{l}0.014 \\
(0.022)\end{array}$ & $\begin{array}{l}-0.014 \\
(0.015)\end{array}$ & $\begin{array}{l}0.060 * * * \\
(0.008)\end{array}$ & $\begin{array}{l}0.061 * * * \\
(0.016)\end{array}$ & $\begin{array}{l}0.036^{* * * *} \\
(0.011)\end{array}$ \\
\hline Industry growth & $\begin{array}{l}0.000 \\
(0.000)\end{array}$ & $\begin{array}{l}0.000 \\
(0.000)\end{array}$ & $\begin{array}{l}0.000 \\
(0.000)\end{array}$ & $\begin{array}{l}-0.000^{* * *} \\
(0.000)\end{array}$ & $\begin{array}{l}-0.000 \text { **** } \\
(0.000)\end{array}$ & $\begin{array}{l}-0.000 \\
(0.000)\end{array}$ \\
\hline Minimum efficient scale & $\begin{array}{l}0.012 \\
(0.107)\end{array}$ & $\begin{array}{l}0.106 \\
(0.182)\end{array}$ & $\begin{array}{l}-0.036 \\
(0.125)\end{array}$ & $\begin{array}{l}-0.080 * * * \\
(0.018)\end{array}$ & $\begin{array}{l}-0.380 \text { *** } \\
(0.104)\end{array}$ & $\begin{array}{l}-0.055^{* * *} \\
(0.019)\end{array}$ \\
\hline Industry concentration & $\begin{array}{l}0.023 * * * \\
(0.009)\end{array}$ & $\begin{array}{l}0.026^{* *} \\
(0.011)\end{array}$ & $\begin{array}{l}0.020 \\
(0.012)\end{array}$ & $\begin{array}{l}0.001 \\
(0.005)\end{array}$ & $\begin{array}{l}0.009 \\
(0.007)\end{array}$ & $\begin{array}{l}-0.009 \\
(0.008)\end{array}$ \\
\hline Nationality of ownership & $\begin{array}{l}0.013 \\
(0.010)\end{array}$ & $\begin{array}{l}0.005 \\
(0.013)\end{array}$ & $\begin{array}{l}0.035 * * \\
(0.014)\end{array}$ & $\begin{array}{l}0.019 * * * \\
(0.004)\end{array}$ & $\begin{array}{l}0.015 * * * \\
(0.005)\end{array}$ & $\begin{array}{l}0.025 * * * \\
(0.006)\end{array}$ \\
\hline Export & $\begin{array}{l}-0.002 \\
(0.011)\end{array}$ & $\begin{array}{l}-0.017 \\
(0.017)\end{array}$ & $\begin{array}{l}-0.003 \\
(0.018)\end{array}$ & $\begin{array}{l}-0.007 * \\
(0.004)\end{array}$ & $\begin{array}{l}-0.012 * * \\
(0.005)\end{array}$ & $\begin{array}{l}-0.002 \\
(0.006)\end{array}$ \\
\hline Import & $\begin{array}{l}0.014 \\
(0.010)\end{array}$ & $\begin{array}{l}0.004 \\
(0.017)\end{array}$ & $\begin{array}{l}0.004 \\
(0.015)\end{array}$ & $\begin{array}{l}-0.008^{* *} \\
(0.004)\end{array}$ & $\begin{array}{l}-0.000 \\
(0.005)\end{array}$ & $\begin{array}{l}-0.019 * * * \\
(0.005)\end{array}$ \\
\hline Export-import & $\begin{array}{l}0.018 \text { *** } \\
(0.007)\end{array}$ & $\begin{array}{l}-0.024 \\
(0.016)\end{array}$ & $\begin{array}{l}0.049 * * * \\
(0.009)\end{array}$ & $\begin{array}{l}0.014 * * * \\
(0.003)\end{array}$ & $\begin{array}{l}-0.012^{* * * *} \\
(0.004)\end{array}$ & $\begin{array}{l}0.047 * * * \\
(0.005)\end{array}$ \\
\hline Training & $\begin{array}{l}0.024 * * * \\
(0.008)\end{array}$ & $\begin{array}{l}0.024 * * \\
(0.012)\end{array}$ & $\begin{array}{l}0.006 \\
(0.012)\end{array}$ & $\begin{array}{l}-0.000 \\
(0.004)\end{array}$ & $\begin{array}{l}0.003 \\
(0.005)\end{array}$ & $\begin{array}{l}-0.012 \\
(0.007)\end{array}$ \\
\hline Subsidies & $\begin{array}{l}0.008 \\
(0.006)\end{array}$ & $\begin{array}{l}0.005 \\
(0.009)\end{array}$ & $\begin{array}{l}0.009 \\
(0.008)\end{array}$ & $\begin{array}{l}0.005 \\
(0.003)\end{array}$ & $\begin{array}{l}0.004 \\
(0.004)\end{array}$ & $\begin{array}{l}0.005 \\
(0.005)\end{array}$ \\
\hline $\mathrm{R} \& \mathrm{D}$ & 0.000 & 0.000 & -0.001 & $-0.000 * * *$ & $-0.000 * * *$ & $0.001 * *$ \\
\hline
\end{tabular}


Table 10 (continued)

\begin{tabular}{|c|c|c|c|c|c|c|}
\hline & \multicolumn{3}{|l|}{ High-tech } & \multicolumn{3}{|l|}{ Low-tech } \\
\hline & $\begin{array}{l}\text { 1991-2007 } \\
\text { I }\end{array}$ & $\begin{array}{l}\text { 1991-2000 } \\
\text { II }\end{array}$ & $\begin{array}{l}\text { 2001-2007 } \\
\text { III }\end{array}$ & $\begin{array}{l}\text { 1991-2007 } \\
\text { IV }\end{array}$ & $\begin{array}{l}1991-2000 \\
\text { V }\end{array}$ & $\begin{array}{l}2001-2007 \\
\text { VI }\end{array}$ \\
\hline & $(0.000)$ & $(0.000)$ & $(0.000)$ & $(0.000)$ & $(0.000)$ & $(0.001)$ \\
\hline \multirow[t]{2}{*}{$\mathrm{R} \& \mathrm{D}$ intensity } & $0.007 * * *$ & 0.009 & -0.036 & $0.004 * * *$ & $0.006^{* *}$ & $0.051^{*}$ \\
\hline & $(0.002)$ & $(0.006)$ & $(0.055)$ & $(0.001)$ & $(0.003)$ & $(0.031)$ \\
\hline \multirow[t]{2}{*}{ Unemployment } & $-0.009 * * *$ & -0.002 & -0.005 & $-0.009^{* * *}$ & $-0.006 * *$ & -0.005 \\
\hline & $(0.003)$ & $(0.005)$ & $(0.009)$ & $(0.002)$ & $(0.003)$ & $(0.005)$ \\
\hline \multirow[t]{2}{*}{ Inflation } & $-0.003 * * *$ & $-0.003 *$ & 0.002 & $-0.001 * *$ & -0.001 & -0.001 \\
\hline & $(0.001)$ & $(0.002)$ & $(0.003)$ & $(0.000)$ & $(0.001)$ & $(0.002)$ \\
\hline \multirow[t]{2}{*}{ Credit } & $0.000 * *$ & 0.001 & -0.000 & 0.000 & $0.001 * *$ & 0.000 \\
\hline & $(0.000)$ & $(0.001)$ & $(0.000)$ & $(0.000)$ & $(0.000)$ & $(0.000)$ \\
\hline \multirow[t]{2}{*}{ Constant } & 0.026 & $0.483 * *$ & 0.030 & $0.266^{* * *}$ & $0.169 * *$ & 0.053 \\
\hline & $(0.097)$ & $(0.222)$ & $(0.092)$ & $(0.035)$ & $(0.077)$ & $(0.060)$ \\
\hline Observations & 11,433 & 6728 & 11,433 & 47,850 & 25,798 & 22,052 \\
\hline$F$ test & 7.752 & 15.85 & 11.84 & 43.42 & 24.07 & 23.12 \\
\hline Number of firms & 1595 & 1240 & 1595 & 6564 & 4469 & 4908 \\
\hline Hansen test & $3.78(0.14)$ & $3.86(0.52)$ & $5.835(0.12)$ & $2.363(0.50)$ & $2.143(0.54)$ & $1.827(0.61)$ \\
\hline $\mathrm{m} 1$ & -9.796 & -7.010 & -10.03 & -26.04 & -19.33 & -17.99 \\
\hline $\mathrm{m} 2$ & 1.973 & 1.900 & 1.849 & 1.827 & 1.455 & 1.605 \\
\hline Instruments & 34 & 34 & 29 & 29 & 29 & 29 \\
\hline
\end{tabular}

Robust standard errors are in parentheses. $\mathrm{m} 1$ and $\mathrm{m} 2$ are the tests for first- and second-order serial correlation in the first-differenced residuals, asymptotically distributed as $N(0,1)$ under the null of no serial correlation. Values in parentheses represent the $p$ values for the Hansen test and $F$ test. Estimates include location dummies

*Significant at $10 \% ; * *$ significant at $5 \%$; ***significant at $1 \%$

Table 11 Determinants of turnover and employment growth — SMEs that remained in the sample during the whole period

\begin{tabular}{|c|c|c|c|c|c|c|}
\hline & \multicolumn{3}{|c|}{ Turnover growth } & \multicolumn{3}{|c|}{ Employment growth } \\
\hline & $\begin{array}{l}\text { 1991-2007 } \\
\text { I }\end{array}$ & $\begin{array}{l}1991-2000 \\
\text { II }\end{array}$ & $\begin{array}{l}2001-2007 \\
\text { III }\end{array}$ & $\begin{array}{l}\text { 1991-2007 } \\
\text { IV }\end{array}$ & $\begin{array}{l}1991-2000 \\
\mathrm{~V}\end{array}$ & $\begin{array}{l}2001-2007 \\
\text { VI }\end{array}$ \\
\hline Log turnover $r_{t-1}$ & $\begin{array}{l}-0.111^{* * *} \\
(0.025)\end{array}$ & $\begin{array}{l}-0.109 * * * \\
(0.022)\end{array}$ & $\begin{array}{l}-0.088^{* * * *} \\
(0.020)\end{array}$ & & & \\
\hline$\left(\text { Log turnover } \text { t }_{t-1}\right)^{2}$ & $\begin{array}{l}0.022 * * * \\
(0.005)\end{array}$ & $\begin{array}{l}0.022 * * * \\
(0.004)\end{array}$ & $\begin{array}{l}0.016 * * * \\
(0.003)\end{array}$ & & & \\
\hline Log employment $t_{t-1}$ & & & & $\begin{array}{l}0.004 \\
(0.018)\end{array}$ & $\begin{array}{l}-0.083 * * * \\
(0.012)\end{array}$ & $\begin{array}{l}-0.195 * * * \\
(0.018)\end{array}$ \\
\hline$(\text { Log employment } t-1)^{2}$ & & & & $\begin{array}{l}-0.006^{*} \\
(0.003)\end{array}$ & $\begin{array}{l}0.008 * * * \\
(0.002)\end{array}$ & $\begin{array}{l}0.025 * * * \\
(0.003)\end{array}$ \\
\hline Log labour productivity ${ }_{t-1}$ & $\begin{array}{l}-0.135^{* * *} \\
(0.015)\end{array}$ & $\begin{array}{l}-0.118^{* * *} \\
(0.013)\end{array}$ & $\begin{array}{l}-0.114 * * * \\
(0.015)\end{array}$ & $\begin{array}{l}0.052 * * * \\
(0.004)\end{array}$ & $\begin{array}{l}0.054 * * * \\
(0.003)\end{array}$ & $\begin{array}{l}0.053 * * * \\
(0.005)\end{array}$ \\
\hline Industry growth & $\begin{array}{l}0.244 * * * \\
(0.019)\end{array}$ & $\begin{array}{l}0.126 * * * \\
(0.023)\end{array}$ & $\begin{array}{l}0.093 * * * \\
(0.018)\end{array}$ & $\begin{array}{l}0.042 * * * \\
(0.009)\end{array}$ & $\begin{array}{l}0.040 * * * \\
(0.014)\end{array}$ & $\begin{array}{l}0.008 \\
(0.011)\end{array}$ \\
\hline
\end{tabular}


Table 11 (continued)

\begin{tabular}{|c|c|c|c|c|c|c|}
\hline & \multicolumn{3}{|c|}{ Turnover growth } & \multicolumn{3}{|c|}{ Employment growth } \\
\hline & $\begin{array}{l}\text { 1991-2007 } \\
\text { I }\end{array}$ & $\begin{array}{l}1991-2000 \\
\text { II }\end{array}$ & $\begin{array}{l}2001-2007 \\
\text { III }\end{array}$ & $\begin{array}{l}\text { 1991-2007 } \\
\text { IV }\end{array}$ & $\begin{array}{l}1991-2000 \\
\mathrm{~V}\end{array}$ & $\begin{array}{l}2001-2007 \\
\text { VI }\end{array}$ \\
\hline Minimum efficient scale & $\begin{array}{l}-0.000^{* * *} \\
(0.000)\end{array}$ & $\begin{array}{l}0.000 \\
(0.000)\end{array}$ & $\begin{array}{l}-0.000^{* *} \\
(0.000)\end{array}$ & $\begin{array}{l}-0.000 * * \\
(0.000)\end{array}$ & $\begin{array}{l}0.000 \\
(0.000)\end{array}$ & $\begin{array}{l}-0.000 \\
(0.000)\end{array}$ \\
\hline Industry concentration & $\begin{array}{l}-0.084 * \\
(0.044)\end{array}$ & $\begin{array}{l}-0.578 * * \\
(0.274)\end{array}$ & $\begin{array}{l}0.130 * * \\
(0.065)\end{array}$ & $\begin{array}{l}-0.078 * * \\
(0.030)\end{array}$ & $\begin{array}{l}-0.250 \\
(0.181)\end{array}$ & $\begin{array}{l}0.047 \\
(0.047)\end{array}$ \\
\hline Nationality of ownership & $\begin{array}{l}0.003 \\
(0.009)\end{array}$ & $\begin{array}{l}-0.006 \\
(0.010)\end{array}$ & $\begin{array}{l}0.002 \\
(0.011)\end{array}$ & $\begin{array}{l}-0.003 \\
(0.006)\end{array}$ & $\begin{array}{l}-0.007 \\
(0.006)\end{array}$ & $\begin{array}{l}-0.011 \\
(0.008)\end{array}$ \\
\hline Export & $\begin{array}{l}0.031 * * * \\
(0.011)\end{array}$ & $\begin{array}{l}0.043 * * * \\
(0.014)\end{array}$ & $\begin{array}{l}0.019 \\
(0.013)\end{array}$ & $\begin{array}{l}-0.012 * \\
(0.007)\end{array}$ & $\begin{array}{l}-0.010 \\
(0.008)\end{array}$ & $\begin{array}{l}-0.022 * * \\
(0.010)\end{array}$ \\
\hline Import & $\begin{array}{l}0.010 \\
(0.008)\end{array}$ & $\begin{array}{l}-0.000 \\
(0.010)\end{array}$ & $\begin{array}{l}0.042 * * * \\
(0.010)\end{array}$ & $\begin{array}{l}-0.007 \\
(0.005)\end{array}$ & $\begin{array}{l}-0.013^{* *} \\
(0.005)\end{array}$ & $\begin{array}{l}-0.005 \\
(0.006)\end{array}$ \\
\hline Export-import & $\begin{array}{l}0.036 * * * \\
(0.009)\end{array}$ & $\begin{array}{l}0.044 * * * \\
(0.011)\end{array}$ & $\begin{array}{l}0.043 * * * \\
(0.010)\end{array}$ & $\begin{array}{l}0.001 \\
(0.005)\end{array}$ & $\begin{array}{l}0.003 \\
(0.005)\end{array}$ & $\begin{array}{l}-0.005 \\
(0.006)\end{array}$ \\
\hline Training & $\begin{array}{l}0.003 \\
(0.006)\end{array}$ & $\begin{array}{l}-0.024 * * * \\
(0.008)\end{array}$ & $\begin{array}{l}0.042 * * * \\
(0.007)\end{array}$ & $\begin{array}{l}0.011 * * * \\
(0.003)\end{array}$ & $\begin{array}{l}-0.013 * * * \\
(0.004)\end{array}$ & $\begin{array}{l}0.041 * * * \\
(0.005)\end{array}$ \\
\hline Subsidies & $\begin{array}{l}0.003 \\
(0.007)\end{array}$ & $\begin{array}{l}-0.005 \\
(0.008)\end{array}$ & $\begin{array}{l}0.033 * * * \\
(0.008)\end{array}$ & $\begin{array}{l}0.008 \\
(0.005)\end{array}$ & $\begin{array}{l}0.003 \\
(0.005)\end{array}$ & $\begin{array}{l}0.009 \\
(0.007)\end{array}$ \\
\hline $\mathrm{R} \& \mathrm{D}$ & $\begin{array}{l}0.015 * * * \\
(0.005)\end{array}$ & $\begin{array}{l}0.009 \\
(0.006)\end{array}$ & $\begin{array}{l}0.046 * * * \\
(0.007)\end{array}$ & $\begin{array}{l}0.001 \\
(0.004)\end{array}$ & $\begin{array}{l}-0.002 \\
(0.004)\end{array}$ & $\begin{array}{l}0.003 \\
(0.004)\end{array}$ \\
\hline R\&D intensity & $\begin{array}{l}-0.000 \text { *** } \\
(0.000)\end{array}$ & $\begin{array}{l}-0.000 * * * \\
(0.000)\end{array}$ & $\begin{array}{l}-0.595 * * * \\
(0.147)\end{array}$ & $\begin{array}{l}-0.000 * * * \\
(0.000)\end{array}$ & $\begin{array}{l}-0.000 * * * \\
(0.000)\end{array}$ & $\begin{array}{l}0.020 \\
(0.014)\end{array}$ \\
\hline Unemployment & $\begin{array}{l}0.004 * * * \\
(0.001)\end{array}$ & $\begin{array}{l}0.034 * * * \\
(0.004)\end{array}$ & $\begin{array}{l}-0.001 \\
(0.042)\end{array}$ & $\begin{array}{l}0.005 * * * \\
(0.001)\end{array}$ & $\begin{array}{l}0.006 * * \\
(0.003)\end{array}$ & $\begin{array}{l}-0.013 \\
(0.030)\end{array}$ \\
\hline Inflation & $\begin{array}{l}0.019 * * * \\
(0.003)\end{array}$ & $\begin{array}{l}0.057 * * * \\
(0.004)\end{array}$ & $\begin{array}{l}-0.020^{* * *} \\
(0.006)\end{array}$ & $\begin{array}{l}-0.009^{* * *} \\
(0.002)\end{array}$ & $\begin{array}{l}-0.006^{* *} \\
(0.002)\end{array}$ & $\begin{array}{l}-0.003 \\
(0.005)\end{array}$ \\
\hline Real effective exchange rate & $\begin{array}{l}-0.003 * * * \\
(0.001)\end{array}$ & $\begin{array}{l}-0.012 * * * \\
(0.001)\end{array}$ & $\begin{array}{l}0.004 * \\
(0.002)\end{array}$ & $\begin{array}{l}-0.002^{* * *} \\
(0.000)\end{array}$ & $\begin{array}{l}-0.000 \\
(0.001)\end{array}$ & $\begin{array}{l}0.001 \\
(0.002)\end{array}$ \\
\hline Credit & $\begin{array}{l}0.001 * * * \\
(0.000)\end{array}$ & $\begin{array}{l}0.005 * * * \\
(0.001)\end{array}$ & $\begin{array}{l}-0.000 \\
(0.000)\end{array}$ & $\begin{array}{l}0.000 \\
(0.000)\end{array}$ & $\begin{array}{l}0.001 \\
(0.000)\end{array}$ & $\begin{array}{l}-0.000 \\
(0.000)\end{array}$ \\
\hline Constant & $\begin{array}{l}0.181 * * * \\
(0.047)\end{array}$ & $\begin{array}{l}0.262 * * * \\
(0.095)\end{array}$ & $\begin{array}{l}-0.119 * \\
(0.067)\end{array}$ & $\begin{array}{l}0.208 * * * \\
(0.039)\end{array}$ & $\begin{array}{l}0.121 * \\
(0.071)\end{array}$ & $\begin{array}{l}0.335 * * * \\
(0.055)\end{array}$ \\
\hline Observations & 21,760 & 19,271 & 17,230 & 21,744 & 19,261 & 17,209 \\
\hline$F$ test & 18,953 & 20,202 & 10.66 & 14.83 & 15.06 & 10.08 \\
\hline Number of firms & 1361 & 2142 & 2471 & 1361 & 2142 & 2471 \\
\hline Hansen test & $2.011(0.57)$ & $3.352(0.34)$ & $4.862(0.18)$ & $1.271(0.74)$ & $1.238(0.74)$ & $3.401(0.33)$ \\
\hline $\mathrm{m} 1$ & -7.598 & -9.363 & -7.341 & -16.27 & -19.84 & -15.28 \\
\hline $\mathrm{m} 2$ & 1.052 & 1.780 & 1.006 & 1.004 & 1.210 & 1.932 \\
\hline Instruments & 46 & 46 & 46 & 46 & 46 & 46 \\
\hline
\end{tabular}

Robust standard errors are in parentheses. $\mathrm{m} 1$ and $\mathrm{m} 2$ are the tests for first- and second-order serial correlation in the first-differenced residuals, asymptotically distributed as $N(0,1)$ under the null of no serial correlation. Values in parentheses represent the $p$ values for the Hansen test and $F$ test. Estimates include industry and location dummies

*Significant at $10 \%$; **significant at 5\%; ***significant at $1 \%$ 
Table 12 Determinants of turnover and employment growth — SMEs that entered the sample during the period

\begin{tabular}{|c|c|c|c|c|c|c|}
\hline & \multicolumn{3}{|c|}{ Turnover growth } & \multicolumn{3}{|c|}{ Employment growth } \\
\hline & $\begin{array}{l}1991-2007 \\
\text { I }\end{array}$ & $\begin{array}{l}1991-2000 \\
\text { II }\end{array}$ & $\begin{array}{l}\text { 2001-2007 } \\
\text { III }\end{array}$ & $\begin{array}{l}\text { 1991-2007 } \\
\text { IV }\end{array}$ & $\begin{array}{l}1991-2000 \\
\text { V }\end{array}$ & $\begin{array}{l}2001-2007 \\
\text { VI }\end{array}$ \\
\hline Log turnover ${ }_{t-1}$ & $\begin{array}{l}-0.096^{* * *} \\
(0.014)\end{array}$ & $\begin{array}{l}-0.127 * * * \\
(0.023)\end{array}$ & $\begin{array}{l}-0.099 * * * \\
(0.035)\end{array}$ & & & \\
\hline$\left(\text { Log turnover } \text { t }_{t-1}\right)^{2}$ & $\begin{array}{l}0.020^{* * *} \\
(0.003)\end{array}$ & $\begin{array}{l}0.030 * * * \\
(0.004)\end{array}$ & $\begin{array}{l}0.019 * * * \\
(0.007)\end{array}$ & & & \\
\hline Log employment $t_{t-1}$ & & & & $\begin{array}{l}-0.137 * * * \\
(0.031)\end{array}$ & $\begin{array}{l}-0.225 * * * \\
(0.058)\end{array}$ & $\begin{array}{l}-0.140 * * * \\
(0.045)\end{array}$ \\
\hline$\left(\text { Log employment } t_{-1}\right)^{2}$ & & & & $\begin{array}{l}0.015 * * * \\
(0.006)\end{array}$ & $\begin{array}{l}0.027 * * * \\
(0.010)\end{array}$ & $\begin{array}{l}0.014 \\
(0.009)\end{array}$ \\
\hline Log labour productivity $_{t-1}$ & $\begin{array}{l}-0.188 * * * \\
(0.011)\end{array}$ & $\begin{array}{l}-0.247 * * * \\
(0.020)\end{array}$ & $\begin{array}{l}-0.160 * * * \\
(0.019)\end{array}$ & $\begin{array}{l}0.045 * * * \\
(0.005)\end{array}$ & $\begin{array}{l}0.044 * * * \\
(0.008)\end{array}$ & $\begin{array}{l}0.052 * * * \\
(0.008)\end{array}$ \\
\hline Industry growth & $\begin{array}{l}0.211 * * * \\
(0.021)\end{array}$ & $\begin{array}{l}0.093 \\
(0.060)\end{array}$ & $\begin{array}{l}0.073 * * \\
(0.033)\end{array}$ & $\begin{array}{l}0.041 * * * \\
(0.012)\end{array}$ & $\begin{array}{l}0.043 \\
(0.032)\end{array}$ & $\begin{array}{l}0.003 \\
(0.026)\end{array}$ \\
\hline Minimum efficient scale & $\begin{array}{l}-0.000 * * * \\
(0.000)\end{array}$ & $\begin{array}{l}0.001 \\
(0.001)\end{array}$ & $\begin{array}{l}0.000 \\
(0.001)\end{array}$ & $\begin{array}{l}-0.000^{* *} \\
(0.000)\end{array}$ & $\begin{array}{l}0.001 \\
(0.000)\end{array}$ & $\begin{array}{l}-0.000 \\
(0.001)\end{array}$ \\
\hline Industry concentration & $\begin{array}{l}0.148 * * \\
(0.065)\end{array}$ & $\begin{array}{l}-1.085 \\
(0.880)\end{array}$ & $\begin{array}{l}-0.243 \\
(0.258)\end{array}$ & $\begin{array}{l}0.062 \\
(0.040)\end{array}$ & $\begin{array}{l}-0.811^{*} \\
(0.458)\end{array}$ & $\begin{array}{l}0.007 \\
(0.211)\end{array}$ \\
\hline Nationality of ownership & $\begin{array}{l}0.057 * * * \\
(0.018)\end{array}$ & $\begin{array}{l}0.123 * * * \\
(0.028)\end{array}$ & $\begin{array}{l}0.031 \\
(0.060)\end{array}$ & $\begin{array}{l}0.039 * * * \\
(0.011)\end{array}$ & $\begin{array}{l}0.068 * * * \\
(0.018)\end{array}$ & $\begin{array}{l}0.025 \\
(0.033)\end{array}$ \\
\hline Export & $\begin{array}{l}0.051 * * * \\
(0.017)\end{array}$ & $\begin{array}{l}0.062 * \\
(0.033)\end{array}$ & $\begin{array}{l}0.044 \\
(0.036)\end{array}$ & $\begin{array}{l}0.002 \\
(0.011)\end{array}$ & $\begin{array}{l}0.007 \\
(0.021)\end{array}$ & $\begin{array}{l}0.019 \\
(0.024)\end{array}$ \\
\hline Import & $\begin{array}{l}0.047 * * * \\
(0.010)\end{array}$ & $\begin{array}{l}-0.043 * \\
(0.024)\end{array}$ & $\begin{array}{l}0.095 * * * \\
(0.020)\end{array}$ & $\begin{array}{l}-0.007 \\
(0.007)\end{array}$ & $\begin{array}{l}-0.033^{* *} \\
(0.015)\end{array}$ & $\begin{array}{l}0.000 \\
(0.016)\end{array}$ \\
\hline Export-import & $\begin{array}{l}0.112 * * * \\
(0.012)\end{array}$ & $\begin{array}{l}0.094 * * * \\
(0.024)\end{array}$ & $\begin{array}{l}0.071 * * * \\
(0.024)\end{array}$ & $\begin{array}{l}-0.015^{* *} \\
(0.006)\end{array}$ & $\begin{array}{l}-0.018 \\
(0.015)\end{array}$ & $\begin{array}{l}-0.039^{* *} \\
(0.016)\end{array}$ \\
\hline Training & $\begin{array}{l}0.048^{* * * *} \\
(0.008)\end{array}$ & $\begin{array}{l}-0.006 \\
(0.017)\end{array}$ & $\begin{array}{l}0.086^{* * * *} \\
(0.019)\end{array}$ & $\begin{array}{l}0.042 * * * \\
(0.005)\end{array}$ & $\begin{array}{l}-0.023^{* *} \\
(0.010)\end{array}$ & $\begin{array}{l}0.078 * * * \\
(0.016)\end{array}$ \\
\hline Subsidies & $\begin{array}{l}0.012 \\
(0.010)\end{array}$ & $\begin{array}{l}-0.026^{*} \\
(0.015)\end{array}$ & $\begin{array}{l}0.080 * * * \\
(0.023)\end{array}$ & $\begin{array}{l}-0.003 \\
(0.007)\end{array}$ & $\begin{array}{l}0.005 \\
(0.010)\end{array}$ & $\begin{array}{l}-0.050^{* * *} \\
(0.018)\end{array}$ \\
\hline $\mathrm{R} \& \mathrm{D}$ & $\begin{array}{l}0.075^{* * *} \\
(0.008)\end{array}$ & $\begin{array}{l}0.036^{* *} \\
(0.016)\end{array}$ & $\begin{array}{l}0.124 * * * \\
(0.021)\end{array}$ & $\begin{array}{l}0.004 \\
(0.005)\end{array}$ & $\begin{array}{l}-0.003 \\
(0.009)\end{array}$ & $\begin{array}{l}-0.027 * \\
(0.014)\end{array}$ \\
\hline $\mathrm{R} \& \mathrm{D}$ intensity & $\begin{array}{l}-0.001 * * * \\
(0.000)\end{array}$ & $\begin{array}{l}-0.001 * * * \\
(0.000)\end{array}$ & $\begin{array}{l}-0.296^{* *} \\
(0.122)\end{array}$ & $\begin{array}{l}0.000 \\
(0.000)\end{array}$ & $\begin{array}{l}0.000 \\
(0.000)\end{array}$ & $\begin{array}{l}0.119 * * * \\
(0.018)\end{array}$ \\
\hline Unemployment & $\begin{array}{l}0.001 \\
(0.002)\end{array}$ & $\begin{array}{l}0.011 \\
(0.014)\end{array}$ & $\begin{array}{l}-4.179 * \\
(2.271)\end{array}$ & $\begin{array}{l}0.009 * * * \\
(0.001)\end{array}$ & $\begin{array}{l}0.005 \\
(0.009)\end{array}$ & $\begin{array}{l}-3.425^{*} \\
(1.983)\end{array}$ \\
\hline Inflation & $\begin{array}{l}0.029 * * * \\
(0.004)\end{array}$ & $\begin{array}{l}0.068 * * * \\
(0.012)\end{array}$ & $\begin{array}{l}0.489 * \\
(0.265)\end{array}$ & $\begin{array}{l}-0.008^{* * *} \\
(0.003)\end{array}$ & $\begin{array}{l}-0.009 \\
(0.007)\end{array}$ & $\begin{array}{l}0.377 \\
(0.232)\end{array}$ \\
\hline Real effective exchange rate & $\begin{array}{l}0.002 * * \\
(0.001)\end{array}$ & $\begin{array}{l}-0.005 \\
(0.006)\end{array}$ & $\begin{array}{l}0.088^{*} \\
(0.049)\end{array}$ & $\begin{array}{l}-0.001 \\
(0.001)\end{array}$ & $\begin{array}{l}-0.002 \\
(0.004)\end{array}$ & $\begin{array}{l}0.070 * \\
(0.042)\end{array}$ \\
\hline Credit & $\begin{array}{l}0.001 * * * \\
(0.000)\end{array}$ & $\begin{array}{l}0.002 \\
(0.002)\end{array}$ & $\begin{array}{l}-0.009 * \\
(0.006)\end{array}$ & $\begin{array}{l}0.000 \\
(0.000)\end{array}$ & $\begin{array}{l}-0.000 \\
(0.001)\end{array}$ & $\begin{array}{l}-0.008 \\
(0.005)\end{array}$ \\
\hline Constant & $\begin{array}{l}-0.334 * * * \\
(0.084)\end{array}$ & $\begin{array}{l}-0.060 \\
(0.414)\end{array}$ & $\begin{array}{l}10.000 * \\
(5.408)\end{array}$ & $\begin{array}{l}0.324 * * * \\
(0.064)\end{array}$ & $\begin{array}{l}0.573 * * \\
(0.266)\end{array}$ & $\begin{array}{l}8.682 * \\
(4.745)\end{array}$ \\
\hline
\end{tabular}


Table 12 (continued)

\begin{tabular}{|c|c|c|c|c|c|c|}
\hline & \multicolumn{3}{|c|}{ Turnover growth } & \multicolumn{3}{|c|}{ Employment growth } \\
\hline & $\begin{array}{l}\text { 1991-2007 } \\
\text { I }\end{array}$ & $\begin{array}{l}\text { 1991-2000 } \\
\text { II }\end{array}$ & $\begin{array}{l}\text { 2001-2007 } \\
\text { III }\end{array}$ & $\begin{array}{l}\text { 1991-2007 } \\
\text { IV }\end{array}$ & $\begin{array}{l}1991-2000 \\
\text { V }\end{array}$ & $\begin{array}{l}2001-2007 \\
\text { VI }\end{array}$ \\
\hline Observations & 22,542 & 7774 & 3895 & 22,488 & 7752 & 3890 \\
\hline$F$ test & 18.16 & 21.92 & 4.422 & 16.76 & 7.072 & 4.476 \\
\hline Number of firms & 4400 & 2110 & 1602 & 4391 & 2105 & 1600 \\
\hline Hansen test & $4.803(0.19)$ & $2.623(0.45)$ & $9.657(0.02)$ & $3.144(0.37)$ & $2.662(0.45)$ & $5.134(0.16)$ \\
\hline $\mathrm{m} 1$ & -10.26 & -6.244 & -6.587 & -18.21 & -9.065 & -7.673 \\
\hline $\mathrm{m} 2$ & 1.903 & 0.756 & 0.865 & 1.358 & 1.059 & 0.891 \\
\hline Instruments & 46 & 46 & 46 & 46 & 46 & 46 \\
\hline
\end{tabular}

Robust standard errors are in parentheses. $\mathrm{m} 1$ and $\mathrm{m} 2$ are the tests for first- and second-order serial correlation in the first-differenced residuals, asymptotically distributed as $N(0,1)$ under the null of no serial correlation. Values in parentheses represent the $p$ values for the Hansen test and $F$ test. Estimates include industry and location dummies

*Significant at $10 \%$; * significant at $5 \%$; ***significant at $1 \%$

Table 13 Determinants of turnover and employment growth — SMEs that left the sample during the period

\begin{tabular}{|c|c|c|c|c|c|c|}
\hline & \multicolumn{3}{|c|}{ Turnover growth } & \multicolumn{3}{|c|}{ Employment growth } \\
\hline & $\begin{array}{l}\text { 1991-2007 } \\
\text { I }\end{array}$ & $\begin{array}{l}\text { 1991-2000 } \\
\text { II }\end{array}$ & $\begin{array}{l}\text { 2001-2007 } \\
\text { III }\end{array}$ & $\begin{array}{l}\text { 1991-2007 } \\
\text { IV }\end{array}$ & $\begin{array}{l}\text { 1991-2000 } \\
\text { V }\end{array}$ & $\begin{array}{l}2001-2007 \\
\text { VI }\end{array}$ \\
\hline Log turnover ${ }_{t-1}$ & $\begin{array}{c}-0.103^{* * * *} \\
(0.014)\end{array}$ & $\begin{array}{c}-0.084 * * * \\
(0.016)\end{array}$ & $\begin{array}{c}-0.214 * * * \\
(0.041)\end{array}$ & & & \\
\hline$\left(\text { Log turnover } \text { t }_{t-1}\right)^{2}$ & $\begin{array}{c}0.024 * * * \\
(0.003)\end{array}$ & $\begin{array}{c}0.022 * * * \\
(0.003)\end{array}$ & $\begin{array}{c}0.034 * * * \\
(0.007)\end{array}$ & & & \\
\hline Log employment $t_{t-1}$ & & & & $\begin{array}{c}-0.142 * * * \\
(0.034)\end{array}$ & $\begin{array}{c}-0.242 * * * \\
(0.083)\end{array}$ & $\begin{array}{c}-0.177 * * * \\
(0.055)\end{array}$ \\
\hline$\left(\text { Log employment }_{t-1}\right)^{2}$ & & & & $\begin{array}{c}0.018 * * * \\
(0.006)\end{array}$ & $\begin{array}{c}0.032 * * \\
(0.014)\end{array}$ & $\begin{array}{c}0.025 * * \\
(0.010)\end{array}$ \\
\hline Log labour productivity $t-1$ & $\begin{array}{c}-0.177 * * * \\
(0.012)\end{array}$ & $\begin{array}{c}-0.175 * * * \\
(0.022)\end{array}$ & $\begin{array}{c}-0.152 * * * \\
(0.024)\end{array}$ & $\begin{array}{c}0.041 * * * \\
(0.005)\end{array}$ & $\begin{array}{c}0.053 * * * \\
(0.010)\end{array}$ & $\begin{array}{c}0.024 * * * \\
(0.009)\end{array}$ \\
\hline Industry growth & $\begin{array}{c}0.239 * * * \\
(0.025)\end{array}$ & $\begin{array}{c}0.156^{* *} \\
(0.065)\end{array}$ & $\begin{array}{l}0.057 * \\
(0.033)\end{array}$ & $\begin{array}{c}0.059 * * * \\
(0.014)\end{array}$ & $\begin{array}{c}0.078 * * \\
(0.038)\end{array}$ & $\begin{array}{c}0.004 \\
(0.025)\end{array}$ \\
\hline Minimum efficient scale & $\begin{array}{l}-0.000 \\
(0.000)\end{array}$ & $\begin{array}{l}0.003 * \\
(0.002)\end{array}$ & $\begin{array}{c}0.000 \\
(0.000)\end{array}$ & $\begin{array}{c}-0.000 * * * \\
(0.000)\end{array}$ & $\begin{array}{c}0.001 \\
(0.001)\end{array}$ & $\begin{array}{l}-0.000 \\
(0.000)\end{array}$ \\
\hline Industry concentration & $\begin{array}{c}0.037 \\
(0.088)\end{array}$ & $\begin{array}{l}-1.616 \\
(1.448)\end{array}$ & $\begin{array}{c}-0.411 * * * \\
(0.154)\end{array}$ & $\begin{array}{c}-0.150 * * * \\
(0.056)\end{array}$ & $\begin{array}{l}-0.526 \\
(0.775)\end{array}$ & $\begin{array}{l}-0.127 \\
(0.120)\end{array}$ \\
\hline Nationality of ownership & $\begin{array}{c}0.010 \\
(0.014)\end{array}$ & $\begin{array}{c}0.057 * * * \\
(0.020)\end{array}$ & $\begin{array}{l}-0.028 \\
(0.031)\end{array}$ & $\begin{array}{c}0.015 * * \\
(0.007)\end{array}$ & $\begin{array}{c}0.035 * * \\
(0.015)\end{array}$ & $\begin{array}{c}0.019 \\
(0.015)\end{array}$ \\
\hline Export & $\begin{array}{c}0.073^{* * * *} \\
(0.018)\end{array}$ & $\begin{array}{c}0.048 \\
(0.030)\end{array}$ & $\begin{array}{c}0.056 \\
(0.035)\end{array}$ & $\begin{array}{l}-0.000 \\
(0.010)\end{array}$ & $\begin{array}{c}0.006 \\
(0.021)\end{array}$ & $\begin{array}{l}-0.000 \\
(0.018)\end{array}$ \\
\hline Import & $\begin{array}{c}0.038^{* * * *} \\
(0.013)\end{array}$ & $\begin{array}{l}-0.003 \\
(0.022)\end{array}$ & $\begin{array}{c}0.147 * * * \\
(0.024)\end{array}$ & $\begin{array}{c}-0.012 * \\
(0.007)\end{array}$ & $\begin{array}{l}-0.022 \\
(0.016)\end{array}$ & $\begin{array}{l}-0.007 \\
(0.013)\end{array}$ \\
\hline Export-import & $\begin{array}{c}0.112 * * * \\
(0.013)\end{array}$ & $\begin{array}{c}0.075 * * * \\
(0.022)\end{array}$ & $\begin{array}{c}0.195 * * * \\
(0.027)\end{array}$ & $\begin{array}{l}-0.007 \\
(0.007)\end{array}$ & $\begin{array}{l}-0.015 \\
(0.016)\end{array}$ & $\begin{array}{c}-0.022 * * \\
(0.011)\end{array}$ \\
\hline
\end{tabular}


Table 13 (continued)

\begin{tabular}{|c|c|c|c|c|c|c|}
\hline & \multicolumn{3}{|c|}{ Turnover growth } & \multicolumn{3}{|c|}{ Employment growth } \\
\hline & $\begin{array}{l}\text { 1991-2007 } \\
\text { I }\end{array}$ & $\begin{array}{l}\text { 1991-2000 } \\
\text { II }\end{array}$ & $\begin{array}{l}\text { 2001-2007 } \\
\text { III }\end{array}$ & $\begin{array}{l}\text { 1991-2007 } \\
\text { IV }\end{array}$ & $\begin{array}{l}\text { 1991-2000 } \\
\text { V }\end{array}$ & $\begin{array}{l}\text { 2001-2007 } \\
\text { VI }\end{array}$ \\
\hline Training & $\begin{array}{c}0.022 * * * \\
(0.008)\end{array}$ & $\begin{array}{l}-0.001 \\
(0.015)\end{array}$ & $\begin{array}{c}0.152 * * * \\
(0.019)\end{array}$ & $\begin{array}{c}0.001 \\
(0.005)\end{array}$ & $\begin{array}{c}-0.035 * * * \\
(0.014)\end{array}$ & $\begin{array}{c}0.059 * * * \\
(0.011)\end{array}$ \\
\hline Subsidies & $\begin{array}{l}-0.012 \\
(0.009)\end{array}$ & $\begin{array}{c}-0.029^{*} \\
(0.016)\end{array}$ & $\begin{array}{c}0.046 * * \\
(0.021)\end{array}$ & $\begin{array}{c}0.009 \\
(0.006)\end{array}$ & $\begin{array}{l}-0.002 \\
(0.010)\end{array}$ & $\begin{array}{l}-0.004 \\
(0.014)\end{array}$ \\
\hline $\mathrm{R} \& \mathrm{D}$ & $\begin{array}{c}0.052 * * * \\
(0.009)\end{array}$ & $\begin{array}{c}0.054 * * * \\
(0.017)\end{array}$ & $\begin{array}{c}0.095 * * * \\
(0.016)\end{array}$ & $\begin{array}{l}0.009 * \\
(0.005)\end{array}$ & $\begin{array}{l}0.018 * \\
(0.011)\end{array}$ & $\begin{array}{c}0.015 \\
(0.011)\end{array}$ \\
\hline R\&D intensity & $\begin{array}{l}-0.000 \\
(0.000)\end{array}$ & $\begin{array}{c}-0.001 * * \\
(0.001)\end{array}$ & $\begin{array}{c}0.002 \\
(0.002)\end{array}$ & $\begin{array}{c}0.000 \\
(0.000)\end{array}$ & $\begin{array}{c}-0.001 * \\
(0.000)\end{array}$ & $\begin{array}{l}-0.000 \\
(0.000)\end{array}$ \\
\hline Unemployment & $\begin{array}{c}0.012 * * * \\
(0.003)\end{array}$ & $\begin{array}{c}0.013 \\
(0.011)\end{array}$ & $\begin{array}{c}0.137 \\
(0.146)\end{array}$ & $\begin{array}{l}0.003 * \\
(0.002)\end{array}$ & $\begin{array}{c}0.019 * * \\
(0.007)\end{array}$ & $\begin{array}{c}0.086 \\
(0.084)\end{array}$ \\
\hline Inflation & $\begin{array}{c}0.025 * * * \\
(0.004)\end{array}$ & $\begin{array}{c}0.032 * * \\
(0.013)\end{array}$ & $\begin{array}{l}-0.025 \\
(0.030)\end{array}$ & $\begin{array}{c}-0.008 * * * \\
(0.003)\end{array}$ & $\begin{array}{c}0.019 * * \\
(0.008)\end{array}$ & $\begin{array}{l}-0.003 \\
(0.019)\end{array}$ \\
\hline Real effective exchange rate & $\begin{array}{c}-0.003 * * * \\
(0.001)\end{array}$ & $\begin{array}{c}-0.011 * * * \\
(0.003)\end{array}$ & $\begin{array}{c}0.001 \\
(0.008)\end{array}$ & $\begin{array}{l}-0.001 \\
(0.001)\end{array}$ & $\begin{array}{c}-0.004 * * \\
(0.002)\end{array}$ & $\begin{array}{l}-0.001 \\
(0.005)\end{array}$ \\
\hline Credit & $\begin{array}{c}0.003 * * * \\
(0.000)\end{array}$ & $\begin{array}{c}0.001 \\
(0.002)\end{array}$ & $\begin{array}{c}0.000 \\
(0.001)\end{array}$ & $\begin{array}{l}-0.000 \\
(0.000)\end{array}$ & $\begin{array}{c}0.002 \\
(0.001)\end{array}$ & $\begin{array}{c}0.000 \\
(0.000)\end{array}$ \\
\hline Constant & $\begin{array}{c}-0.131 * \\
(0.076)\end{array}$ & $\begin{array}{c}0.362 \\
(0.277)\end{array}$ & $\begin{array}{c}-0.560 * * \\
(0.266)\end{array}$ & $\begin{array}{c}0.338 * * * \\
(0.065)\end{array}$ & $\begin{array}{c}0.293 \\
(0.217)\end{array}$ & $\begin{array}{c}0.005 \\
(0.187)\end{array}$ \\
\hline Observations & 23,355 & 7016 & 6512 & 23,262 & 6979 & 6469 \\
\hline$F$ test & 15.89 & 4.453 & 4.979 & 15.58 & 6.323 & 4.697 \\
\hline Number of firms & 4258 & 1879 & 2215 & 4242 & 1869 & 2193 \\
\hline Hansen test & $5.110(0.16)$ & $6.678(0.08)$ & $3.088(0.38)$ & $2.692(0.44)$ & $1.186(0.76)$ & $7.734(0.05)$ \\
\hline $\mathrm{m} 1$ & -10.53 & -6.787 & -4.576 & -18.05 & -11.49 & -8.836 \\
\hline $\mathrm{m} 2$ & 1.701 & 1.837 & 1.384 & 1.329 & 1.013 & 1.060 \\
\hline Instruments & 46 & 46 & 46 & 46 & 46 & 46 \\
\hline
\end{tabular}

Robust standard errors are in parentheses. $\mathrm{m} 1$ and $\mathrm{m} 2$ are the tests for first- and second-order serial correlation in the first-differenced residuals, asymptotically distributed as $N(0,1)$ under the null of no serial correlation. Values in parentheses represent the $p$ values for the Hansen test and $F$ test. Estimates include industry and location dummies

$*$ Significant at $10 \%$; * significant at $5 \%$; ***significant at $1 \%$

Table 14 Determinants of employment and turnover growth - SMEs which ceased to be so during the period ${ }^{\mathrm{a}}$

\begin{tabular}{|c|c|c|c|c|c|c|}
\hline & \multicolumn{3}{|c|}{ Employment growth } & \multicolumn{3}{|c|}{ Turnover growth } \\
\hline & $\begin{array}{l}\text { 1991-2007 } \\
\text { I }\end{array}$ & $\begin{array}{l}1991-2000 \\
\text { II }\end{array}$ & $\begin{array}{l}2001-2006 \\
\text { III }\end{array}$ & $\begin{array}{l}\text { 1991-2007 } \\
\text { IV }\end{array}$ & $\begin{array}{l}1991-2000 \\
\text { V }\end{array}$ & $\begin{array}{l}2001-2006 \\
\text { VI }\end{array}$ \\
\hline Log employment $t-1$ & $\begin{array}{l}-0.294 \\
(0.200)\end{array}$ & $\begin{array}{l}-0.124 \\
(0.183)\end{array}$ & $\begin{array}{l}-1.009 \\
(0.892)\end{array}$ & & & \\
\hline$\left(\text { Log employment } t_{t-1}\right)^{2}$ & $\begin{array}{l}0.034 \\
(0.029)\end{array}$ & $\begin{array}{l}0.012 \\
(0.027)\end{array}$ & $\begin{array}{l}0.126 \\
(0.112)\end{array}$ & & & \\
\hline
\end{tabular}


Table 14 (continued)

\begin{tabular}{|c|c|c|c|c|c|c|}
\hline & \multicolumn{3}{|c|}{ Employment growth } & \multicolumn{3}{|c|}{ Turnover growth } \\
\hline & $\begin{array}{l}\text { 1991-2007 } \\
\text { I }\end{array}$ & $\begin{array}{l}\text { 1991-2000 } \\
\text { II }\end{array}$ & $\begin{array}{l}\text { 2001-2006 } \\
\text { III }\end{array}$ & $\begin{array}{l}\text { 1991-2007 } \\
\text { IV }\end{array}$ & $\begin{array}{l}1991-2000 \\
\text { V }\end{array}$ & $\begin{array}{l}\text { 2001-2006 } \\
\text { VI }\end{array}$ \\
\hline Log turnover $r_{t-1}$ & & & & $\begin{array}{l}-0.038 \\
(0.081)\end{array}$ & $\begin{array}{l}-0.050 \\
(0.094)\end{array}$ & $\begin{array}{l}-0.590 \\
(0.764)\end{array}$ \\
\hline$\left(\log _{\text {turnover }}{ }_{t-1}\right)^{2}$ & & & & $\begin{array}{l}0.008 \\
(0.009)\end{array}$ & $\begin{array}{l}0.015 \\
(0.009)\end{array}$ & $\begin{array}{l}0.047 \\
(0.078)\end{array}$ \\
\hline Log labour productivity ${ }_{t-1}$ & $\begin{array}{l}-0.018 \\
(0.036)\end{array}$ & $\begin{array}{l}-0.023 \\
(0.028)\end{array}$ & $\begin{array}{l}0.059 \\
(0.149)\end{array}$ & $\begin{array}{l}-0.306^{* * *} \\
(0.061)\end{array}$ & $\begin{array}{l}-0.330 * * * \\
(0.062)\end{array}$ & $\begin{array}{l}-0.110 \\
(0.147)\end{array}$ \\
\hline Industry growth & $\begin{array}{l}0.076 \\
(0.089)\end{array}$ & $\begin{array}{l}0.462 \\
(0.350)\end{array}$ & $\begin{array}{l}0.007 \\
(0.577)\end{array}$ & $\begin{array}{l}0.148 \\
(0.128)\end{array}$ & $\begin{array}{l}0.206 \\
(0.240)\end{array}$ & $\begin{array}{l}-0.196 \\
(0.212)\end{array}$ \\
\hline Minimum efficient scale & $\begin{array}{l}-0.004 \\
(0.004)\end{array}$ & $\begin{array}{l}-0.009 \\
(0.011)\end{array}$ & $\begin{array}{l}0.001 \\
(0.003)\end{array}$ & $\begin{array}{l}-0.003 \\
(0.003)\end{array}$ & $\begin{array}{l}0.001 \\
(0.007)\end{array}$ & $\begin{array}{l}0.002 \\
(0.002)\end{array}$ \\
\hline Industry concentration & $\begin{array}{l}11.554 \\
(10.592)\end{array}$ & $\begin{array}{l}10.337 \\
(12.184)\end{array}$ & $\begin{array}{l}0.770 \\
(7.733)\end{array}$ & $\begin{array}{l}7.685 \\
(9.884)\end{array}$ & $\begin{array}{l}-2.621 \\
(7.926)\end{array}$ & $\begin{array}{l}2.280 \\
(2.384)\end{array}$ \\
\hline Nationality of ownership & $\begin{array}{l}0.001 \\
(0.086)\end{array}$ & $\begin{array}{l}0.053 \\
(0.079)\end{array}$ & $\begin{array}{l}0.072 \\
(0.526)\end{array}$ & $\begin{array}{l}0.188 * * \\
(0.088)\end{array}$ & $\begin{array}{l}0.219 * * \\
(0.093)\end{array}$ & $\begin{array}{l}0.129 \\
(0.230)\end{array}$ \\
\hline Export & $\begin{array}{l}-0.123 \\
(0.166)\end{array}$ & $\begin{array}{l}0.032 \\
(0.114)\end{array}$ & $\begin{array}{l}-0.571 \\
(0.474)\end{array}$ & $\begin{array}{l}0.133 \\
(0.230)\end{array}$ & $\begin{array}{l}0.349^{*} \\
(0.199)\end{array}$ & $\begin{array}{l}-0.247 \\
(0.365)\end{array}$ \\
\hline Import & $\begin{array}{l}0.041 \\
(0.076)\end{array}$ & $\begin{array}{l}-0.020 \\
(0.071)\end{array}$ & $\begin{array}{l}-0.061 \\
(0.342)\end{array}$ & $\begin{array}{l}0.113 \\
(0.202)\end{array}$ & $\begin{array}{l}0.086 \\
(0.221)\end{array}$ & $\begin{array}{l}0.140 \\
(0.284)\end{array}$ \\
\hline Export-import & $\begin{array}{l}0.109 * \\
(0.062)\end{array}$ & $\begin{array}{l}0.145^{*} \\
(0.073)\end{array}$ & $\begin{array}{l}-0.337 \\
(0.379)\end{array}$ & $\begin{array}{l}0.269 \\
(0.217)\end{array}$ & $\begin{array}{l}0.312 \\
(0.255)\end{array}$ & $\begin{array}{l}0.193 \\
(0.304)\end{array}$ \\
\hline Training & $\begin{array}{l}-0.093 \\
(0.058)\end{array}$ & $\begin{array}{l}-0.070 \\
(0.046)\end{array}$ & $\begin{array}{l}0.019 \\
(0.142)\end{array}$ & $\begin{array}{c}-0.084 \\
(0.071)\end{array}$ & $\begin{array}{l}-0.072 \\
(0.065)\end{array}$ & $\begin{array}{l}0.063 \\
(0.122)\end{array}$ \\
\hline Subsidies & $\begin{array}{l}-0.054 \\
(0.058)\end{array}$ & $\begin{array}{l}0.019 \\
(0.033)\end{array}$ & $\begin{array}{l}-0.140 \\
(0.144)\end{array}$ & $\begin{array}{l}-0.008 \\
(0.069)\end{array}$ & $\begin{array}{l}0.045 \\
(0.061)\end{array}$ & $\begin{array}{l}0.068 \\
(0.125)\end{array}$ \\
\hline $\mathrm{R} \& \mathrm{D}$ & $\begin{array}{l}0.084 \\
(0.125)\end{array}$ & $\begin{array}{l}0.029 \\
(0.084)\end{array}$ & $\begin{array}{l}0.015 \\
(0.114)\end{array}$ & $\begin{array}{l}0.075 \\
(0.136)\end{array}$ & $\begin{array}{l}-0.056 \\
(0.078)\end{array}$ & $\begin{array}{l}-0.068 \\
(0.111)\end{array}$ \\
\hline R\&D intensity & $\begin{array}{l}-0.000 \\
(0.000)\end{array}$ & $\begin{array}{l}-0.000 \\
(0.000)\end{array}$ & $\begin{array}{l}-0.025 \\
(0.102)\end{array}$ & $\begin{array}{l}-0.000 * * * \\
(0.000)\end{array}$ & $\begin{array}{l}-0.001 * * * \\
(0.000)\end{array}$ & $\begin{array}{l}0.092 \\
(0.062)\end{array}$ \\
\hline Unemployment & $\begin{array}{l}0.022 \\
(0.020)\end{array}$ & $\begin{array}{l}0.012 \\
(0.025)\end{array}$ & $\begin{array}{l}0.142 \\
(0.881)\end{array}$ & $\begin{array}{l}0.048 * \\
(0.026)\end{array}$ & $\begin{array}{l}0.048 \\
(0.035)\end{array}$ & $\begin{array}{l}0.000 \\
(0.000)\end{array}$ \\
\hline Inflation & $\begin{array}{l}0.040 \\
(0.042)\end{array}$ & $\begin{array}{l}0.019 \\
(0.041)\end{array}$ & $\begin{array}{l}-0.015 \\
(0.191)\end{array}$ & $\begin{array}{l}0.055 \\
(0.042)\end{array}$ & $\begin{array}{l}0.030 \\
(0.032)\end{array}$ & $\begin{array}{l}-0.060 \\
(0.088)\end{array}$ \\
\hline Real effective exchange rate & $\begin{array}{l}0.003 \\
(0.005)\end{array}$ & $\begin{array}{l}-0.011 \\
(0.010)\end{array}$ & $\begin{array}{l}-0.007 \\
(0.045)\end{array}$ & $\begin{array}{l}-0.007 \\
(0.006)\end{array}$ & $\begin{array}{l}-0.021 * * \\
(0.009)\end{array}$ & $\begin{array}{l}-0.001 \\
(0.006)\end{array}$ \\
\hline Credit & $\begin{array}{l}0.002 \\
(0.002)\end{array}$ & $\begin{array}{l}0.002 \\
(0.004)\end{array}$ & $\begin{array}{l}-0.003 \\
(0.005)\end{array}$ & $\begin{array}{l}0.007 * * \\
(0.003)\end{array}$ & $\begin{array}{l}0.007 \\
(0.005)\end{array}$ & $\begin{array}{l}-0.002 \\
(0.005)\end{array}$ \\
\hline Constant & $\begin{array}{l}0.254 \\
(0.498)\end{array}$ & $\begin{array}{l}1.512 \\
(1.678)\end{array}$ & $\begin{array}{l}2.908 \\
(2.166)\end{array}$ & $\begin{array}{l}-0.249 \\
(0.590)\end{array}$ & $\begin{array}{l}0.583 \\
(1.128)\end{array}$ & $\begin{array}{l}2.246 \\
(2.008)\end{array}$ \\
\hline Observations & 766 & 622 & 144 & 767 & 622 & 145 \\
\hline$F$ test & 2.578 & 3.249 & 3.939 & 39.46 & 12.10 & 32.08 \\
\hline Number of firms & 133 & 120 & 47 & 133 & 120 & 47 \\
\hline Hansen test & $1.236(0.74)$ & $0.377(0.95)$ & $1.708(0.64)$ & $2.979(0.40)$ & $2.869(0.41)$ & $2.988(0.39)$ \\
\hline
\end{tabular}


Table 14 (continued)

\begin{tabular}{|c|c|c|c|c|c|c|}
\hline & \multicolumn{3}{|c|}{ Employment growth } & \multicolumn{3}{|c|}{ Turnover growth } \\
\hline & $\begin{array}{l}1991-2007 \\
\text { I }\end{array}$ & $\begin{array}{l}1991-2000 \\
\text { II }\end{array}$ & $\begin{array}{l}2001-2006 \\
\text { III }\end{array}$ & $\begin{array}{l}\text { 1991-2007 } \\
\text { IV }\end{array}$ & $\begin{array}{l}1991-2000 \\
\text { V }\end{array}$ & $\begin{array}{l}2001-2006 \\
\text { VI }\end{array}$ \\
\hline $\mathrm{m} 1$ & -4.013 & -4.331 & -2.165 & -1.529 & -1.480 & 0.131 \\
\hline $\mathrm{m} 2$ & 0.069 & 0.230 & 0.971 & 1.353 & 1.206 & 0.068 \\
\hline Instruments & 45 & 45 & 40 & 45 & 45 & 40 \\
\hline
\end{tabular}

Robust standard errors are in parentheses. $\mathrm{m} 1$ and $\mathrm{m} 2$ are the tests for first- and second-order serial correlation in the first-differenced residuals, asymptotically distributed as $N(0,1)$ under the null of no serial correlation. Values in parentheses represent the $p$ values for the Hansen test and $F$ test. Estimates include industry and location dummies

${ }^{a}$ SMEs which ceased to be are defined as SMEs which exited the sample due to becoming large firms

$*$ Significant at $10 \%$; * significant at $5 \%$;**significant at $1 \%$

Open Access This article is distributed under the terms of the Creative Commons Attribution 4.0 International License (http:// creativecommons.org/licenses/by/4.0/), which permits unrestricted use, distribution, and reproduction in any medium, provided you give appropriate credit to the original author(s) and the source, provide a link to the Creative Commons license, and indicate if changes were made.

\section{References}

Andreosso-O'Callaghan, B., \& Lenihan, H. (2011). Responding to the crisis: are policies aimed at a strong indigenous industrial base a necessary condition for sustainable economic growth? Policy Studies, 32(4), 325-345. doi:10.1080 /01442872.2011.571850.

Arora, A., \& Gambardella, A. (2005). The globalization of the software industry: perspectives and opportunities for developed and developing countries. Innovation Policy and the Economy, 5(1), 1-32. doi:10.3386/w10538.

Artz, K. W., Norman, P. M., Hatfield, D. E., \& Cardinal, L. B. (2010). A longitudinal study of the impact of $R \& D$, patents, and product innovation on firm performance. Journal of Product Innovation Management, 27(5), 725-740. doi:10.1111/j.1540-5885.2010.00747.x.

Audretsch, D. B. (2004). Sustaining innovation and growth: public policy support for entrepreneurship. Industry and Innovation, 11(3), 167-191. doi:10.1080/1366271042000265366.

Bailey, D., \& Lenihan, H. (2015). A critical reflection on Irish industrial policy: a strategic choice approach. International Journal of the Economics of Business, 22(1), 47-71. doi:10.1080/13571516.2014.993218.

Bartelsman, E., Haltiwanger, J., \& Scarpetta, S. (2009). Measuring and analyzing cross-country differences in firm dynamics. In T. Dunne, J. B. Jensen, \& M. J. Roberts (Eds.), Producer dynamics: new evidence from micro data (pp. 15-76). Chicago: University of Chicago Press.
Beck, T., Demirgüç-Kunt, A., \& Maksimovic, V. (2005). Financial and legal constraints to growth: does firm size matter? The Journal of Finance, 60(1), 137-177. doi:10.1111/j.15406261.2005.00727.x.

Bernini, C., \& Pellegrini, G. (2011). How are growth and productivity in private firms affected by public subsidy? Evidence from a regional policy. Regional Science and Urban Economics, 41(3), 253-265. doi:10.1016/j. regsciurbeco.2011.01.005.

Bigsten, A., \& Gebreeyesus, M. (2007). The small, the young, and the productive: determinants of manufacturing firm growth in Ethiopia. Economic Development and Cultural Change, 55(4), 813-840. doi:10.1086/516767.

Bottazzi, G., Secchi, A., \& Tamagni, F. (2008). Productivity, profitability and financial performance. Industrial and Corporate Change, 17(4), 711-751. doi:10.1093/icc/dtn027.

Buckley, P. J., \& Ruane, F. (2006). Foreign direct investment in Ireland: policy implications for emerging economies. The World Economy, 29(11), 1611-1628. doi:10.1111/j.14679701.2006.00860.x.

Caglayan, M., \& Demir, F. (2014). Firm productivity, exchange rate movements, sources of finance, and export orientation. World Development, 54, 204-219. doi:10.1016/j. worlddev.2013.08.012.

Castellani, D., Serti, F., \& Tomasi, C. (2010). Firms in international trade: importers' and exporters' heterogeneity in Italian manufacturing industry. The World Economy, 33(3), 424457. doi:10.1111/j.1467-9701.2010.01262.x.

Caves, R. E. (1998). Industrial organization and new findings on the turnover and mobility of firms. Journal of Economic Literature, 36(4), 1947-1982.

CEDEFOP (2011). The impact of vocational education and training on company performance. $R P 19$, European Centre for the Development of Vocational Training Research, Luxembourg: Publications Office of the EU. http://www. cedefop.europa.eu/EN/Files/5519_en.pdf. Accessed 3 October 2016

Christopherson, S. (2015). How does financialization affect manufacturing investment? Preliminary evidence from the US and UK. In J. R. Bryson, J. Clark, \& V. Vanchan (Eds.), 
Handbook of manufacturing industries in the world economy (pp. 42-57). Cheltenham: Edward Elgar.

Coad, A. (2009). The growth of firms: a survey of theories and empirical evidence. Cheltenham: Edward Elgar.

Coad, A., \& Rao, R. (2008). Innovation and firm growth in high tech sectors: a quantile regression approach. Research Policy, 37(4), 633-648. doi:10.1016/j.respol.2008.01.003.

CSO (2014) Business in Ireland, 2012. Central Statistics Office, Dublin: Stationery Office.

Daunfeldt, S., \& Elert, N. (2013). When is Gibrat's law a law? Small Business Economics, 41(1), 133-147. doi:10.1007 /s11187-011-9404-x.

del Valle, I. D., \& Castillo, M. A. S. (2009). Human capital and sustainable competitive advantage: an analysis of the relationship between training and performance. International Entrepreneurship and Management Journal, 5(2), 139-163. doi:10.1007/s11365-008-0090-3.

Delmar, F., \& Wennberg, K. (2010). Knowledge-intensive entrepreneurship: the birth, growth and demise of entrepreneurial firms. Cheltenham: Edward Elgar.

Department of Jobs, Enterprises and Innovation (2015). Evaluations of state supports for Enterprise, July 2015. Dublin: Department of Jobs, Enterprises and Innovation.

Dineen, D. J., Kennedy, J., \& Palcic, D. (2012). Ireland: from good example to major warning. In A. Bhushan (Ed.), How to prevent the next crisis: lessons from country experiences of the global financial crisis (pp. 29-54). Ontario: The NorthSouth Institute.

Duch, N., Montolio, D., \& Mediavilla, M. (2009). Evaluating the impact of public subsidies on a firm's performance: a quasiexperimental approach. Investigaciones Regionales, 16, 143165.

European Commission (2012). EU SMEs in 2012: at the crossroads. In Annual report on small and medium-sized enterprises in the EU, 2011/12. Rotterdam: Ecorys.

European Commission (2011). Key figures on European businesses with a special feature on SMEs. Luxembourg: Publications office of the European Union.

European Commission (2003) SME definition user guide and model declaration. Enterprise and Industry Publications. http://ec.europa.eu/enterprise/policies/sme/files/sme definition/sme_user_guide_en.pdf. Accessed 28 January 2015

European Commission (2002a). Communication from the Commission to the Council-Progress report concerning the reduction and reorientation of state aid, $\mathrm{COM} / 2002 / 555$ final, Brussels: European Commission. http://eur-lex.europa. eu/. Accessed 1 October 2016

European Commission (2002b). State aid scorecard, Spring 2002 update, COM/2002/0242 final, Brussels: European Commission. http://eur-lex.europa.eu/. Accessed 1 October 2016

EU KLEMS (2011). EU KLEMS growth and productivity accounts. http://www.euklems.net/. Accessed 25 January 2016

Halkos, G. E., \& Tzeremes, N. G. (2010). The effect of foreign ownership on SMEs performance: an efficiency analysis perspective. Journal of Productivity Analysis, 34(2), 167180. doi:10.1007/s11123-010-0174-2.

Haller, S. A. (2012). Intra-firm trade, exporting, importing and firm performance. Canadian Journal of Economics, 45(4), 1397-1430. doi:10.1111/j.1540-5982.2012.01736.x.
Haapanen, M., Lenihan, H., \& Mariani, M. (2014). Government policy failure in public support for research and development. Policy Studies, 35(6), 557-575. doi:10.1080 /01442872.2014.971728.

Holly, S., Petrella, I., \& Santoro, E. (2013). Aggregate fluctuations and the cross-sectional dynamics of firm growth. Journal of the Royal Statistical Society: Series A (Statistics in Society), 176(2), 459-479. doi:10.1111/j.1467-985X.2012.01047.x.

Honohan, P. (2010). The Irish banking crisis: regulatory and financial stability policy 2003-2008. A Report to the Minister for Finance by the Governor of the Central Bank. Dublin: Government Publications Office. http://www. bankinginquiry.gov.ie/The $\% 20$ Irish $\% 20$ Banking\%20 Crisis $\% 20$ Regulatory $\% 20$ and $\% 20$ Financial $\% 20$ Stability\%20Policy\%202003-2008.pdf. Accessed 6 October 2016

Huynh, K. P., Petrunia, R. J., \& Voia, M. (2010). The impact of initial financial state on firm duration across entry cohorts. Journal of Industrial Economics, 58(3), 661-689. doi:10.1111/j.1467-6451.2010.00429.x.

Jones, P., Beynon, M. J., Pickernell, D., \& Packham, G. (2013). Evaluating the impact of different training methods on SME business performance. Environment and Planning $C$ : Government and Policy, 31(1), 56-81. doi:10.1068/c12113b.

Jovanovic, B. (1982). Selection and the evolution of industry. Econometrica, 50(3), 649-670. doi:10.2307/1912606.

Lai, Y. G., Saridakis, G., Blackburn, R., \& Johnstone, S. (2016). Are the HR responses of small firms different from large firms in times of recession? Journal of Business Venturing, 31(1), 113-131. doi:10.1016/j.jbusvent.2015.04.005.

Lockett, A., Thompson, S., \& Morgenstern, U. (2009). The development of the resource-based view of the firm: a critical appraisal. International Journal of Management Reviews, 11(1), 9-28. doi:10.1111/j.1468-2370.2008.00252.x.

Lotti, F., Santarelli, E., \& Vivarelli, M. (2009). Defending Gibrat's law as a long-run regularity. Small Business Economics, 32(1), 31-44. doi:10.1007/s11187-007-9071-0.

Love, J. H., \& Ganotakis, P. (2013). Learning by exporting: lessons from high-technology SMEs. International Business Review, 22(1), 1-17. doi:10.1016/j.ibusrev.2012.01.006.

Mateev, M., \& Anastasov, Y. (2011). On the growth of micro, small and medium-sized firms in central and Eastern Europe: a dynamic panel analysis. Banking and Finance Review, 3(2), 81-104.

Mazzucato, M., \& Parris, S. (2015). High-growth firms in changing competitive environments: the US pharmaceutical industry (1963 to 2002). Small Business Economics, 44(1), 145170. doi:10.1007/s11187-014-9583-3.

Navaretti, G. B., Castellani, D., \& Pieri, F. (2014). Age and firm growth: evidence from three European countries. Small Business Economics, 43(4), 823-837. doi:10.1007/s11187014-9564-6.

Nelson, R. R., \& Winter, S. G. (1982). An evolutionary theory of economic change. Cambridge: Harvard University Press.

Nunes, P. J., Serrasqueiro, Z. M., \& Leitão, J. (2013a). Assessing the nonlinear nature of the effects of R\&D intensity on growth of SMEs: a dynamic panel data approach. Journal of Evolutionary Economics, 23(1), 97-128. doi:10.1007 /s00191-011-0258-9.

Nunes, P. J., Gonçalves, M., \& Serrasqueiro, Z. M. (2013b). The influence of age on SMEs' growth determinants: empirical 
evidence. Small Business Economics, 40(2), 249-272. doi:10.1007/s11187-011-9363-2.

OECD (2012). OECD compendium of productivity measures. http://www.oecd.org/std/productivity-stats/2012 oecdcompendiumofproductivitymeasures.htm. Accessed 3 October 2016

Ó Riain, S. (2004). Falling over the competitive edge. In M. Peillon and M.P. Corcoran (Eds.), Place and nonplace: the reconfiguration of Ireland. Irish Sociological Chronicles, 4, (pp. 19-29). Dublin: Institute of Public Administration.

Peric, M., \& Vitezic, V. (2016). Impact of global economic crisis on firm growth. Small Business Economics, 46(1), 1-12. doi:10.1007/s11187-015-9671-z.

Regling, K., \& Watson, M. (2010). A preliminary report on the sources of Ireland's banking crisis. Dublin: Government Publications Office. http://www.bankinginquiry.gov. ie/Preliminary \%20Report $\% 20$ into \%20Ireland's \% 20 Banking\%20Crisis\%2031\%20May\%202010.pdf. Accessed 7 May 2016

Reid, G. C. (2006). The foundation of small business enterprise: an entrepreneurial analysis of small firm inception and growth. London: Routledge.
Rigtering, J. P. C., Kraus, S., Eggers, F., \& Jensen, S. H. (2014). A comparative analysis of the entrepreneurial orientation/ growth relationship in service firms and manufacturing firms. Service Industries Journal, 34(4), 275-294. doi:10.1080 /02642069.2013.778978.

Roodman, D. (2009a). How to do xtabond2: an introduction to difference and system GMM in Stata. The Stata Journal, 9(1), 86-136.

Roodman, D. (2009b). A note on the theme of too many instruments. Oxford Bulletin of Economics and Statistics, 71(1), 135-158. doi:10.1111/j.1468-0084.2008.00542.x.

Stam, E. (2010). Growth beyond Gibrat: firm growth processes and strategies. Small Business Economics, 35(2), 129-135. doi:10.1007/s11187-010-9294-3.

Vogel, A., \& Wagner, J. (2010). Higher productivity in importing German manufacturing firms: self-selection, learning from importing, or both? Review of World Economics, 145(4), 641-665. doi:10.1007/s10290-009-0031-4.

World Bank (2012). World development indicators. Washington: World Bank.

Yang, C., \& Huang, C. (2005). R\&D, size and firm growth in Taiwan's electronics industry. Small Business Economics, 25(5), 477-487. doi:10.1007/s11187-004-6487-7. 